\title{
Interaction of Functionalized Naphthalenophanes with Abasic Sites in DNA: DNA Cleavage, DNA Cleavage Inhibition, and Formation of Ligand-DNA Adducts
}

\author{
Coralie Caron, ${ }^{[a, b]}$ Xuan N. T. Duong, ${ }^{[a, b]}$ Régis Guillot, ${ }^{[c]}$ Sophie Bombard, ${ }^{[a, b]}$ and Anton Granzhan*[a,b]
}

\begin{abstract}
Ligands interacting with abasic (AP) sites in DNA may generate roadblocks in base-excision DNA repair (BER) due to indirect inhibition of DNA repair enzymes (e.g., APE1) and/or formation of toxic byproducts, resulting from ligand-induced strand cleavage or covalent cross-links. Herein, we prepared and systematically studied a series of 12 putative AP-site ligands, sharing the common naphthalenophane scaffold but endowed with a variety of substituents. Our results demonstrate that most naphthalenophanes bind to AP-sites in DNA and inhibit the APE1-induced hydrolysis of the latter in vitro. Remarkably, their APE1 inhibitory activity, as characterized by $\mathrm{IC}_{50}$ and $K_{\mathrm{l}}$ values, can be directly related to their affinity and selectivity to AP-sites, assessed from the fluorescencemelting experiments. On the other hand, the molecular design of naphthalenophanes has crucial influence on their intrinsic AP-site cleavage activity (i.e., ligand-catalyzed $\beta$ - and $\beta, \delta$-elimination reactions at the AP site), as illustrated by the compounds either having an exceptionally high AP-site cleavage activity (e.g., 2,7-BisNP-S, 125-fold more efficacious than spermine) or totally devoid of this activity (four compounds). Finally, we reveal the unprecedented formation of a stable covalent DNA adduct upon reaction of one ligand (2,7-BisNP-NH) with its own product of AP-site cleavage.
\end{abstract}

\section{Introduction}

Apurinic/apyrimidinic (AP, or abasic) sites represent common DNA lesions that naturally occur through deglycosylation of DNA, or through DNA glycosylase-catalyzed removal of damaged (deaminated, alkylated or oxidized) DNA bases. ${ }^{[1-3]}$ In the context of chemotherapy employing DNA-alkylating drugs (e.g., MMS or temozolomide), the major DNA alkylation product, $N^{7}$ methylguanine, undergoes spontaneous depurination leading to formation of AP sites, ${ }^{[4]}$ as well as a reaction with histone

\footnotetext{
[a] C. Caron, X. N. T. Duong, Dr. S. Bombard, Dr. A. Granzhan CNRS UMR9187, INSERM U1196

Institut Curie, PSL Research University

F-91405, Orsay (France)

E-mail: anton.granzhan@curie.fr

[b] C. Caron, X. N. T. Duong, Dr. S. Bombard, Dr. A. Granzhan CNRS UMR9187, INSERM U1196

Université Paris Sud, Université Paris-Saclay

F-91405, Orsay (France)

[c] Dr. R. Guillot

CNRS UMR8182, Institut de Chimie Moléculaire et des Matériaux d'Orsay (ICMMO), Université Paris Sud, Université Paris-Saclay 91405 Orsay (France)
}

Supporting information for this article is given via a link at the end of the document. proteins leading to generation of DNA-protein crosslinks. ${ }^{[5]}$ While the latter are thought to be cytotoxic, AP sites are instantly processed by the base excision DNA repair (BER) pathway, which eliminates the drug-induced DNA damage and leads to chemoresistance..$^{[4,6-8]}$ It has been demonstrated that inhibition of BER increases the sensitivity of cancer cells towards DNAalkylating drugs in certain cancers, leading to a therapeutically useful synergic effect. ${ }^{[9,10]}$ Accordingly, significant efforts have been devoted to the development of small-molecule inhibitors of AP endonuclease 1 (APE1, class II AP endonuclease), the key enzyme of the BER pathway that hydrolytically cleaves DNA at AP sites leaving a $3^{\prime}-\mathrm{OH}$ end (Scheme 1, top). ${ }^{[11-13]}$ An alternative promising approach to blocking the BER pathway relies on DNA-binding drugs that selectively bind to AP sites and thereby mask them, or render them unreactive towards from APE1. Thus, methoxyamine (MX, or TRC102) and related alkoxyamines, which form covalent oxime adducts with abasic sites, demonstrate synergy with DNA-alkylating cytotoxic drugs, ${ }^{[14,15]}$ and a combination of $M X$ with temozolomide is currently being evaluated for glioblastoma treatment in a Phase II clinical trial. ${ }^{[16]}$

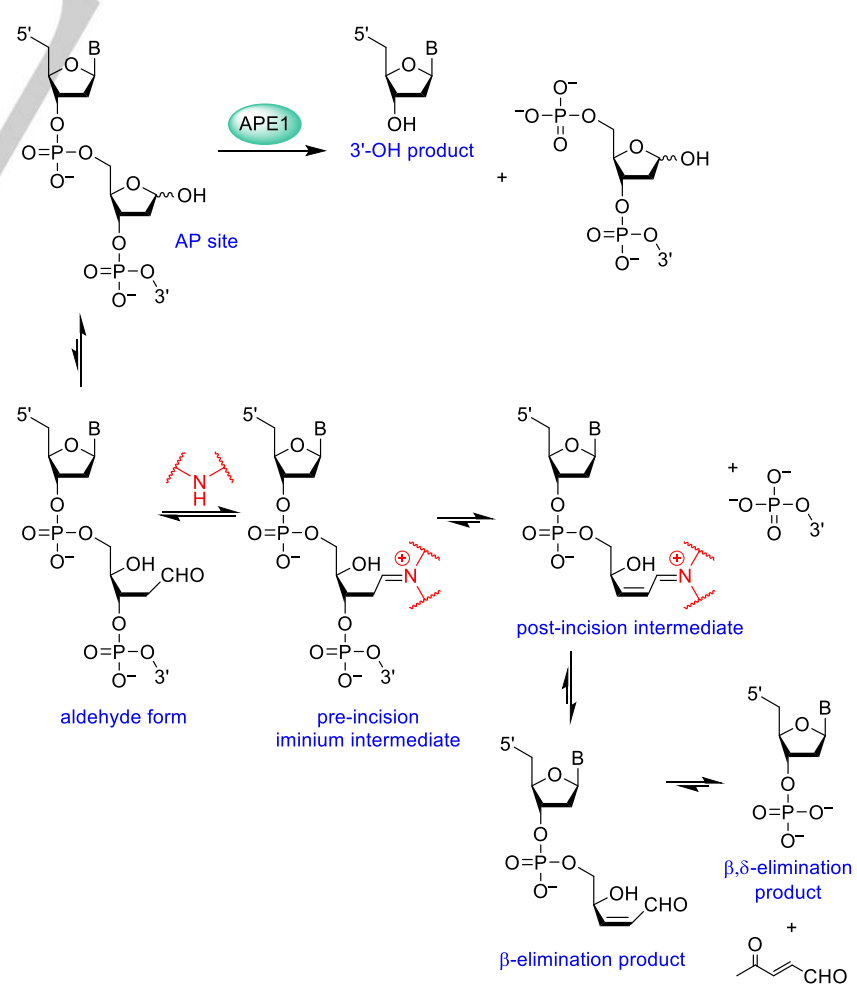

Scheme 1. DNA cleavage at AP sites through APE1-catalysed hydrolysis (top) and $\beta, \delta$-elimination catalyzed by secondary amines (bottom). 
Beyond covalent trapping of abasic sites with reactive drugs such as MX or analogues, several classes of non-covalent ligands were shown to selectively bind to abasic sites in DNA and potentially hinder their recognition and processing by APE1. ${ }^{[17-22]}$ Along these lines, polyazacyclophanes such as bisacridine Bis $\mathrm{A}^{[23,24]}$ and bis-naphthalenes 2,7-BisNP-O and 2,7BisNP-NH (Figure 1) bind to abasic sites with high affinity and selectivity, outperforming other known ligands. ${ }^{25,26]}$ We demonstrated that these compounds inhibit the activity of APE1 in vitro with high efficiency, comparable to that of the best catalytic APE1 inhibitors. ${ }^{[25]}$ However, in parallel to inhibiting APE1 activity, polyazacyclophane ligands also induce an enzyme-independent cleavage of abasic sites via a $\beta$-elimination mechanism, due to the presence of secondary amino groups in the ligand structure (Scheme 1, bottom). ${ }^{[23,25]}$ The latter process, reminiscent to the action of AP lyases (class I endonucleases), was also observed for oligopeptides $\mathrm{KWK}$ and $\mathrm{KWKK}^{[27-29]}$ as well as several other small-molecule ligands endowed with primary or secondary amino groups, eponymously termed "artificial AP lyases". ${ }^{[17,30-34]}$ It has been proposed that such molecules may interfere with the normal BER process because of the accumulation of "dirty ends" (products of $\beta$ - and $\beta, \delta$ elimination) that cannot be utilized as substrates by DNA polymerases, and therefore also increase the cytotoxic effect of DNA-alkylating drugs. ${ }^{[35,36]}$
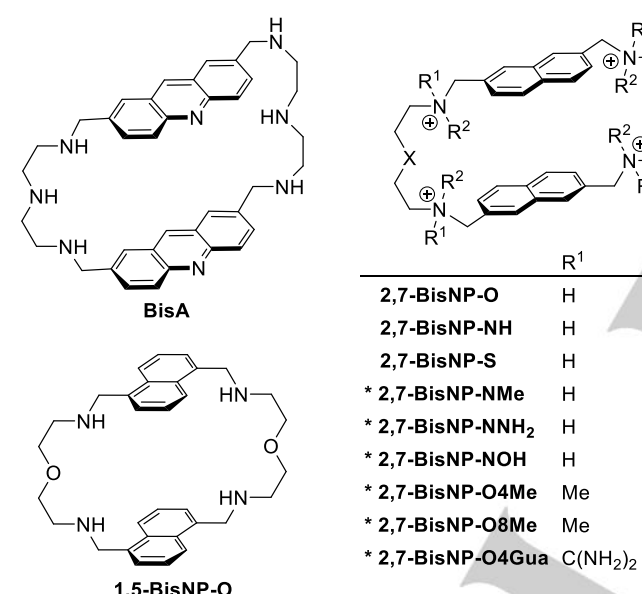

2,7-BisNP-S

2,7-BisNP-NMe

* 2,7-BisNP-NMe $\mathrm{H}$

$\mathrm{H} \quad \mathrm{N}\left(\mathrm{CH}_{2}\right)_{3} \mathrm{NH}_{2}$

*2,7-BisNP-NOH $\mathrm{H} \quad \mathrm{H} \quad \mathrm{N}\left(\mathrm{CH}_{2}\right)_{3} \mathrm{OH}$

*2,7-BisNP-O4Me Me $\mathrm{H} \quad \mathrm{O}$

*2,7-BisNP-O8Me Me Me O

* 2,7-BisNP-O4Gua $\mathrm{C}\left(\mathrm{NH}_{2}\right)_{2}-\mathrm{O}$
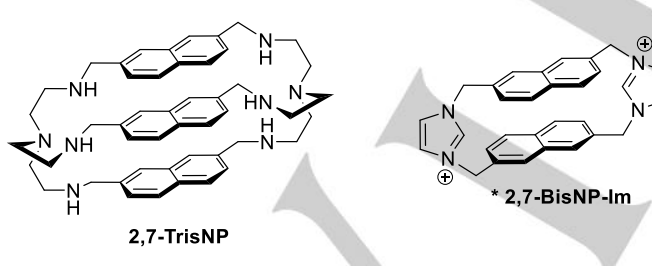

Figure 1. Structures of previously reported and $\left({ }^{*}\right)$ novel polyazacyclophane ligands. The counter-ions are omitted for clarity.

In order to fully understand the action of ligands targeting abasic sites in biological systems, it would be preferable to decouple the two aforementioned effects, namely the inhibition of the APE1-induced hydrolysis and the ligand-promoted cleavage of AP sites. Towards this end, we designed a novel series of functionalized macrocycles based on the previously established 2,7-naphthalenophane scaffold (Figure 1) and including, among others, ligands conceived either to be devoid of AP-DNA cleavage activity due to the absence of nucleophilic groups (2,7-BisNP-O8Me, 2,7-BisNP-O4Gua, 2,7-BisNP-Im) or, conversely, to possess an enhanced AP-site cleavage activity (2,7-BisNP-NNH ${ }_{2}$ ). Herein, we report the synthesis of novel ligands, a systematic investigation of their AP-DNA binding affinity and selectivity, in vitro interference with the APE1 processing of abasic sites, as well as the assessment of their intrinsic reactivity towards AP-sites in DNA.

\section{Results and Discussion}

\section{Synthesis of novel naphthalenophane ligands}

All novel naphthalenophanes were prepared from the common starting material, 2,7-bis(bromomethyl)naphthalene 1 (Scheme 2). The imidazolium-linked cyclophane 2,7-BisNP-Im was obtained, as a bromide salt, in a two-step reaction of $\mathbf{1}$ with imidazole, performed in an analogy to the reported procedures. ${ }^{[37-40]}$ Kornblum oxidation of 1 gave, in a $52 \%$ yield, naphthalene-2,7-dialdehyde 3 , a mutual intermediate for the synthesis of all polyamine-type macrocycles obtained through a $[2+2]$-type condensation with the corresponding diamines. Thus, a reaction of 3 with 2,2'-oxybis(ethylamine), followed by the reduction of tetraimine intermediate 4 with $\mathrm{NaBH}_{4}$, gave the previously described macrocycle 2,7-BisNP-O, which was subsequently converted to the tetramethylated derivative 2,7BisNP-O4Me via Eschweiler-Clarke reaction $(\mathrm{HCHO} / \mathrm{HCOOH})$ or to the octamethylated analogue 2,7-BisNP-O8Me by exhaustive methylation (Mel, DIPEA). A tetraguanidine derivative 2,7-BisNP-O4Gua was obtained, as a hydrochloride salt, through a treatment of 2,7-BisNP-O with N,N'-di-Boc-Smethylisothiourea in the presence of $\mathrm{HgCl}_{2}$, followed by the removal of Boc groups $\left(\mathrm{HCl}\right.$ in $\left.\mathrm{CHCl}_{3}\right)$. Finally, three derivatives of hexaazamacrocycle 2,7-BisNP-NH with varied substituents at two middle nitrogen atoms (2,7-BisNP-NMe, $-\mathbf{N N H}_{2}$ and $\left.-\mathbf{N O H}\right)$ were prepared by condensation of $\mathbf{3}$ with the correspondingly substituted derivatives of diethylenetriamine, followed by $\mathrm{NaBH}_{4}$ reduction and conversion to water-soluble hydrochloride salts.

The structures of 2,7-BisNP-Im $\left(2 \mathrm{Br}^{-}\right)$and 2,7-BisNPO4Gua $\times 4 \mathrm{HCl}$ were investigated by single-crystal X-ray diffraction analysis. In the case of the imidazolium-linked cyclophane, both naphthalene units were found to be strictly coplanar, and the two anti-oriented imidazolium moieties were nearly perpendicular to the plane of naphthalene units (Figure 2a). Remarkably, a coplanar geometry of aromatic units is without precedent in the well-studied series of bis-imidazolium cyclophanes since, to the best of our knowledge, all previously described anti-conformers adopted a displaced anti-parallel conformation of aromatic units. ${ }^{[38-40]}$ At the same time, ${ }^{1} \mathrm{H}$ NMR spectra of 2,7-BisNP-Im revealed a sharp singlet for methylene protons at room temperature $\left(\delta=5.77 \mathrm{ppm}\right.$, in $\left.\left[\mathrm{D}_{6}\right] \mathrm{DMSO}\right)$, giving evidence of a rapid interconversion of all possible conformations (presumably, due to the intramolecular rotation of imidazolium rings) on the NMR time scale. 


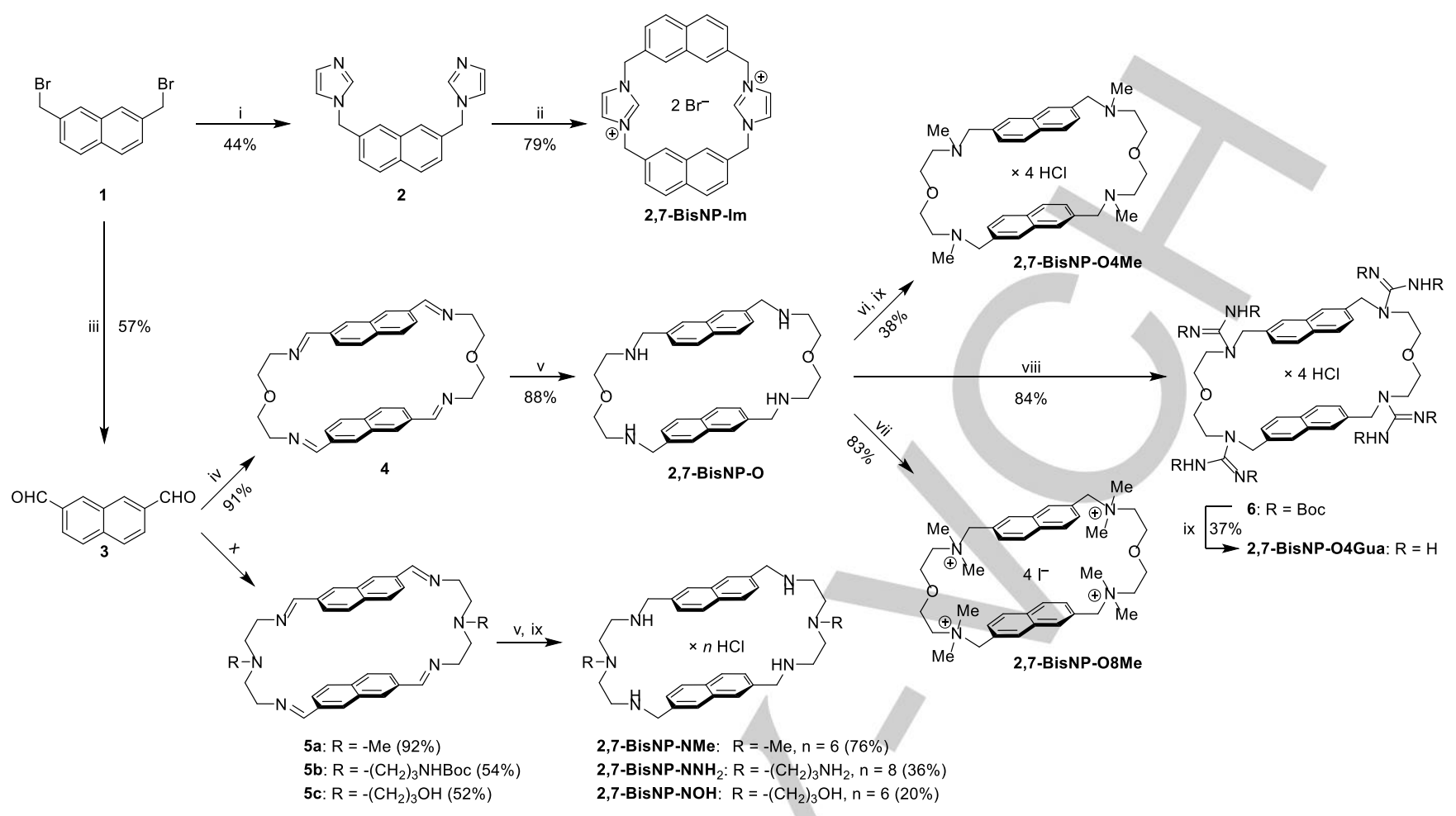

Scheme 2. Synthesis of functionalized naphthalenophane ligands. Reagents and conditions: (i) imidazole, $\mathrm{MeOH}$, reflux, $22 \mathrm{~h}$; (ii) 1 , MeCN, $90{ }^{\circ} \mathrm{C}$, $18 \mathrm{~h}$; (iii) $\mathrm{NaHCO}_{3}, \mathrm{DMSO}, 100{ }^{\circ} \mathrm{C}$; (iv) $\mathrm{O}\left(\mathrm{CH}_{2} \mathrm{CH}_{2} \mathrm{NH}_{2}\right)_{2}, \mathrm{MeCN}$, room temp., 4 days; (v) $\mathrm{NaBH}_{4}, \mathrm{DCM}-\mathrm{MeOH}$, room temp.; (vi) $\mathrm{HCHO}, \mathrm{HCOOH}, 120{ }^{\circ} \mathrm{C}, 48 \mathrm{~h}$; (vii) $\mathrm{Mel}$ (excess), DIPEA, DMF, $60^{\circ} \mathrm{C}, 24 \mathrm{~h}$; (viii) BocN=C(SMe)NHBoc, $\mathrm{HgCl}_{2}, \mathrm{NEt}_{3}, \mathrm{DCM}$, room temp., $48 \mathrm{~h}$; (ix) $\mathrm{HCl}$ (dioxane), CHCl 3 , room temp., $24 \mathrm{~h}$; (x) $\mathrm{RN}\left(\mathrm{CH}_{2} \mathrm{CH}_{2} \mathrm{NH}_{2}\right)_{2}, \mathrm{MeCN}$, room temp., 4 days; then $\mathrm{HCl}$ (dioxane), $\mathrm{MeOH}$.

a)

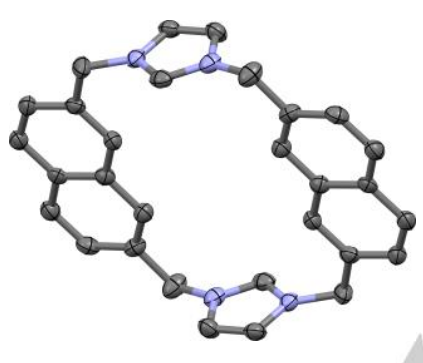

b)

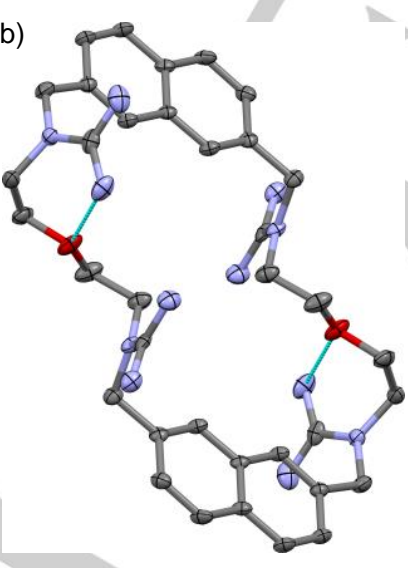

Figure 2. Solid-state structures (ORTEP plots, from single crystal X-ray diffraction analysis): a) 2,7-BisNP-Im $\left(2 \mathrm{Br}^{-}\right)$, viewed along to the crystallographic $c$ axis; b) 2,7-BisNP-O4Gua $\times 4 \mathrm{HCl} \times 5 \mathrm{H}_{2} \mathrm{O}$, viewed along the crystallographic $b$ axis. Thermal ellipsoids are drawn at $70 \%$ probability; cyan lines: intramolecular hydrogen bonds. Hydrogen atoms, counter-ions and solvent molecules are omitted for the sake of clarity.

The tetraguanidine macrocycle crystallized with naphthalene units in a displaced anti-parallel conformation (Figure $2 b$ ). The conformation of linkers reveals a significant potential of molecular flexibility in aqueous solutions, in spite of the intramolecular hydrogen bonds observed, in the solid state, between the protonated guanidinium groups and oxygen atoms of the linkers.

\section{AP-DNA affinity of ligands assessed by fluorescence- melting experiments}

The interaction of ligands with abasic sites was studied through fluorescence-melting experiments with double-stranded oligonucleotides 17-NФ (Table 1, $\Phi=$ THF abasic site), bearing abasic sites opposite to different orphan residues $(\mathrm{N}=\mathrm{T}, \mathrm{C}, \mathrm{A}$ or $\mathrm{G})$, a quencher (TAMRA) on the abasic strand, and a fluorophore (6-FAM) on the complementary strand. The use of the stable THF analogue of AP sites in these experiments avoids the ligand-promoted DNA cleavage during the melting ramps, and a relatively low ionic strength of the buffer $\left(20 \mathrm{mM} \mathrm{K}^{+}\right.$, $\mathrm{pH}$ 7.2) allows the observation of even weak stabilization effects, expressed as ligand-induced increase of denaturation temperature $\left(\Delta T_{\mathrm{m}}\right)$. In addition, AP-site selectivity of ligands with respect to well-matched DNA was estimated through analysis of the drop of $\Delta T_{\mathrm{m}}$ values observed in the presence of unlabeled double-stranded competitor (calf thymus DNA, 200- or 650-fold excess with respect to the AP target). In parallel, thermal denaturation experiments performed with the fully matched duplex (17-TA) provide another measure of the selectivity of ligands with respect to undamaged DNA. 
Table 1. Sequences and melting temperatures of 17-mer oligonucleotides used in this work. ${ }^{\text {a] }}$

5'-F-CCAG TTC GNA GTA ACCC-3'

3'-Q-GGTC AAG CYT CAT TGGG-5'

\begin{tabular}{llll}
\hline Acronym & $\mathrm{N}$ & $\mathrm{Y}^{[\mathrm{b}]}$ & \multicolumn{1}{c}{$T_{\mathrm{m}}{ }^{\circ}{ }^{\circ} \mathrm{C}$} \\
\hline $17-\mathrm{T} \Phi$ & $\mathrm{T}$ & $\Phi$ & $32.0 \pm 0.1^{[\mathrm{c}]}$ \\
$17-\mathrm{C} \Phi$ & $\mathrm{C}$ & $\Phi$ & $31.9 \pm 0.1^{[\mathrm{c}]}$ \\
$17-\mathrm{G} \Phi$ & $\mathrm{G}$ & $\Phi$ & $33.7 \pm 0.1^{[\mathrm{c}]}$ \\
$17-\mathrm{A} \Phi$ & $\mathrm{A}$ & $\Phi$ & $33.8 \pm 0.2^{[\mathrm{c}]}$ \\
$17-\mathrm{TA}$ & $\mathrm{T}$ & $\mathrm{A}$ & $45.0 \pm 0.1^{[\mathrm{cc}]}$ \\
$17-\mathrm{TU}$ & $\mathrm{T}$ & $\mathrm{dU}$ & $\mathrm{n} . \mathrm{d}$. \\
$17-\mathrm{TX}$ & $\mathrm{T}$ & $\mathrm{X}$ & $46.6 \pm 0.2^{[\mathrm{d}]}$ \\
\hline
\end{tabular}

[a] In the fluorescence-melting assay, $F=6-F A M, Q=T A M R A$; in fluorimetric DNA cleavage studies, $F=A T T O 390, Q=D A B C Y L$. [b] $\Phi=$ THF abasic site; $\mathrm{X}=$ native abasic site. [c] In $10 \mathrm{mM} \mathrm{KAsO} \mathrm{Me}_{2}, 10 \mathrm{mM} \mathrm{KCl}$, $\mathrm{pH} 7.2$ (conditions of the fluorescence-melting assay). [d] In $10 \mathrm{mM} \mathrm{KAsO}_{2} \mathrm{Me}_{2}, 150 \mathrm{mM} \mathrm{KCl}, \mathrm{pH}$ 7.2 (conditions of the fluorimetric DNA cleavage assay). Data are means \pm s.d. from three technical replicates.

The results of fluorescence-melting experiments are presented in Figure 3. All ligands stabilized the abasic duplexes, to an extent depending on the base facing the AP site: 17-TФ > 17-C $\Phi>17-G \Phi>17-A \Phi$. Remarkably, none of the ligands of the 2,7-BisNP series stabilized the well-matched duplex 17-TA, in contrast to ethidium bromide (used as a control, non-selective DNA binder) and 1,5-BisNP-O, which, in spite of its structural similarity, has a different substitution pattern of naphthalene units and whose non-specific binding to fully matched DNA was previously documented. ${ }^{[41]}$ In addition, the selectivity of most ligands of the 2,7-BisNP series for abasic oligonucleotides was confirmed by the fact that the presence of double-stranded competitor only slightly decreased the ligand-induced stabilization effect. Considering the effect of substituents introduced into the naphthalenophane scaffold with respect to parent ligands (2,7-BisNP-NH and 2,7-BisNP-O), the following observations emerge from the results presented in Figure 3:

1) Macrocycles bearing substituents at middle nitrogen atoms of the linkers (2,7-BisNP-NMe, - $\mathbf{N N H}_{2}$, - $\left.\mathbf{N O H}\right)$ demonstrate the stabilization effect equal to, or even higher than the one induced by "parent" ligands, for all abasic substrates (e.g., $\Delta T_{\mathrm{m}}^{\top \Phi} \approx 10^{\circ} \mathrm{C}$ ), in combination with excellent selectivity with respect to competitor DNA. This gives evidence that side chains introduced in the middle of polyamine linkers do not hamper the binding of naphthalenophanes to AP sites. In contrast, the sulfur analogue 2,7-BisNP-S was both less efficient (e.g., $\Delta T_{\mathrm{m}}{ }^{\top \Phi} \approx 8^{\circ} \mathrm{C}$ ) and less selective, with respect to all abasic substrates.

2) The stabilization induced by the ligands bearing substituents at the benzylic amino groups $\left(R^{1}, R^{2} \neq H\right.$, i.e., 2,7BisNP-O4Me, 2,7-BisNP-08Me, 2,7-BisNP-O4Gua) was lower, compared to the "parent" ligand 2,7-BisNP-O, in par- ticular upon binding to $17-\mathrm{T} \Phi\left(\Delta T_{\mathrm{m}}{ }^{\top \Phi} \leq 8^{\circ} \mathrm{C}\right)$ and 17-G $\Phi$ $\left(\Delta T_{\mathrm{m}}{ }^{\mathrm{G} \Phi} \leq 4^{\circ} \mathrm{C}\right)$. The loss of efficiency was most pronounced in the case of 2,7-BisNP-O4Me $\left(\Delta T_{\mathrm{m}}{ }^{\top \Phi}=5.4^{\circ} \mathrm{C}, \Delta T_{\mathrm{m}}^{\mathrm{G} \Phi}=\right.$ $\left.2.0^{\circ} \mathrm{C}\right)$. These observations support the structural model observed upon binding of 2,7-BisNP-O to a T-T mismatch $^{[42]}$ and suggest that the substituents at the benzylic amino groups impede the hydrogen bonding of protonated amines to carbonyl groups of orphan $\mathrm{G}$ or $\mathrm{T}$ residues, reducing the overall stabilization of the ligand-AP site complex.
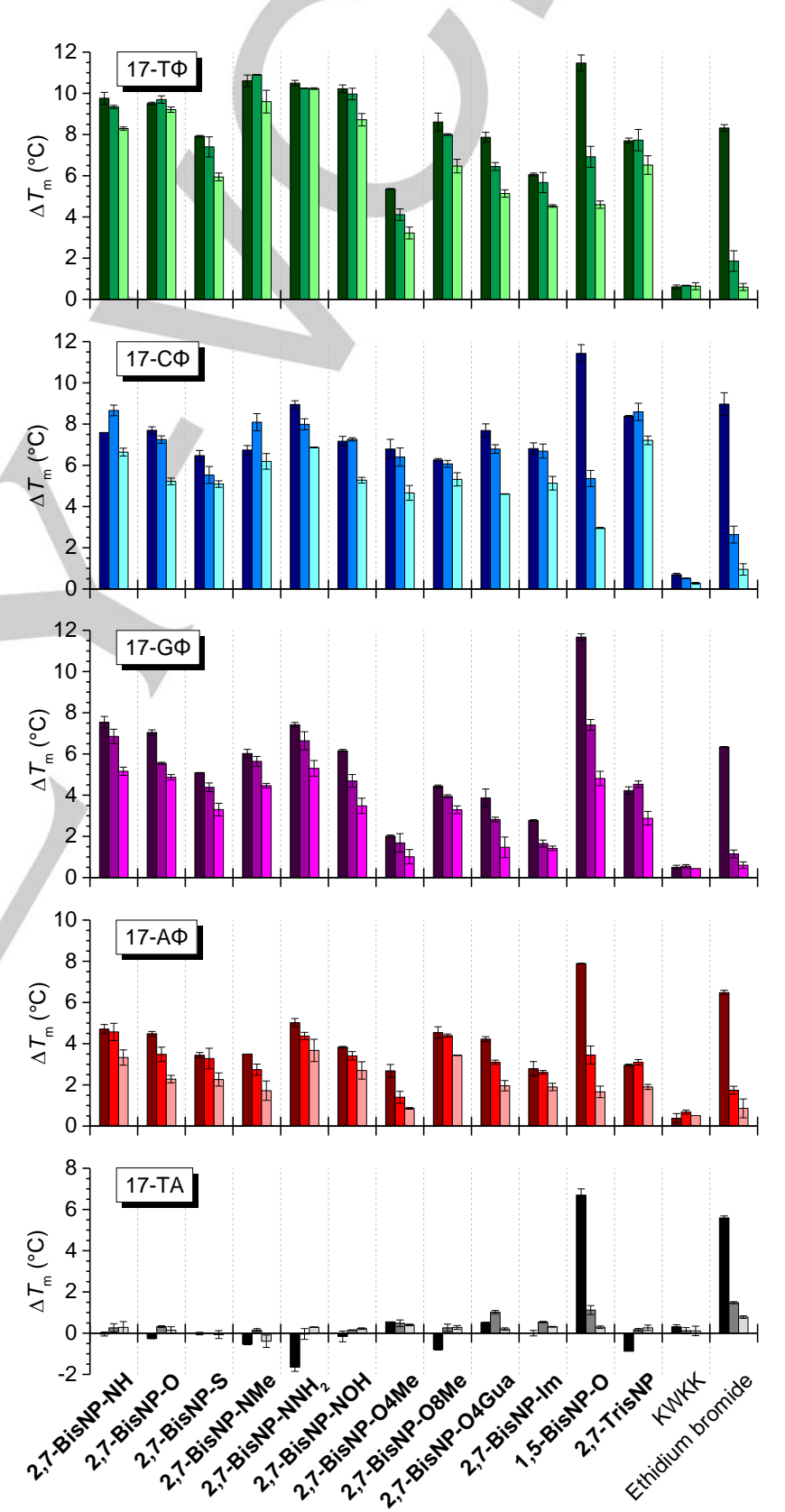

Figure 3. Ligand-induced shifts of melting temperature $\left(\Delta T_{\mathrm{m}}\right)$ of abasic oligonucleotides (17-NФ) or the well-matched control (17-TA), in the absence (dark bars) or in the presence of ct DNA competitor (medium bars: $20 \mu \mathrm{M}$ bp, light bars: $65 \mu \mathrm{M}$ bp). Conditions: $c$ (oligo) $=0.5 \mu \mathrm{M}, c$ (ligand) $=1 \mu \mathrm{M}$ in $10 \mathrm{mM}$ $\mathrm{KAsO}_{2} \mathrm{Me}_{2}, 10 \mathrm{mM} \mathrm{KCl}$ buffer, $\mathrm{pH}$ 7.2. Data are means \pm s.d. from three technical replicates. 
3) Quite remarkably, the effect of the bicyclophane 2,7-TrisNP and the bis-imidazolium cyclophane 2,7-BisNP-Im is very similar to the one of polyazacyclophane ligands, in spite of their significantly different shapes. In the case of 2,7TrisNP, this may be rationalized taking into account its shape similarity to cylindrical metallohelicates which bind to abasic sites with high affinity, even though the structural details of their binding mode have not yet been elucidated. ${ }^{[22]}$ As for 2,7-BisNP-Im, this ligand may bind to AP sites in a conformation which is significantly different from the one observed in the solid state (cf. Figure 2a), most likely in a folded form allowing the insertion of one of naphthalene units inside the abasic pocket.

\section{Inhibition of enzymatic DNA cleavage}

To study the competitive effect of the ligands on the enzymatic processing of AP sites, we used a real-time fluorimetric assay similar to the one employed in our previous work. ${ }^{[25]}$ In this assay, APE1-induced cleavage of the abasic substrate 17-TФ (Table 1) is monitored through the fluorescence increase which occurs upon cleavage and dehybridization of the quencher-bearing strand (Figure 4a). However, in preliminary experiments we observed that oligonucleotides labelled with 6-FAM, as well as with several other conventional fluorophores such as Alexa Fluor (AF) 488, AF 546, AF 594, TAMRA, or Texas Red, underwent significant quenching upon addition of most ligands. While this ligand-induced quenching is tolerable in fluorescence-melting experiments (which aim at measuring the temperature of the melting transition and do not account for the exact fluorescence intensity), this phenomenon could bias the output of kinetic assays. Therefore, in order to minimize the extent of ligandinduced quenching, ATTO390 was employed as the fluorophore least prone to this phenomenon, in combination with DABCYL quencher. ${ }^{[43]}$

The results of the kinetic assay demonstrated that all ligands were able to inhibit APE1 activity in a dose-dependent manner (Figure $4 \mathrm{~b}$ and Supporting Information, Figure S1), with the corresponding $\mathrm{IC}_{50}$ values ranging from $0.14 \mu \mathrm{M}$ (2,7-BisNP$\left.\mathbf{N N H}_{2}\right)$ to $89 \mu \mathrm{M}(\mathbf{2}, 7-B i s N P-O 4 M e$, Table 2). Taking into account the fact that indirect inhibition is described by the same mathematical model as competitive inhibition (i.e., $V_{\max }=$ const, $K_{\mathrm{M}}^{\text {app }}=\alpha K_{\mathrm{M}}$, where $\left.\alpha=1+[\mathrm{l}] / K_{\mathrm{l}}\right)$, with the only difference that the inhibition constant $\left(K_{l}\right)$ represents the dissociation constant of the inhibitor-substrate (and not inhibitor-enzyme) complex, ${ }^{[25]}$ we calculated the corresponding $K_{l}$ values (Table 2) using the well-known relationship (Eq. 1):[44]

$$
\mathrm{IC}_{50}=K_{\mathrm{I}}\left(1+S / K_{\mathrm{M}}\right) \text {, }
$$

where $S$ is concentration of the substrate $(0.2 \mu \mathrm{M})$ and $K_{\mathrm{M}}$ is Michaelis constant for APE1 $\left(K_{\mathrm{M}}=76 \mathrm{nM}\right.$, Supporting Information, Figure S2). ${ }^{[45]}$ Of note, the $K_{\mathrm{l}}$ values for the macrocycles 2,7-BisNP-NH and 2,7-BisNP-O $(\approx 50 \mathrm{nM})$ were of the same order as the ones obtained in our previous work (34 nM) despite a significantly lower concentration of the substrate $(25 \mathrm{nM}) .{ }^{[25]}$

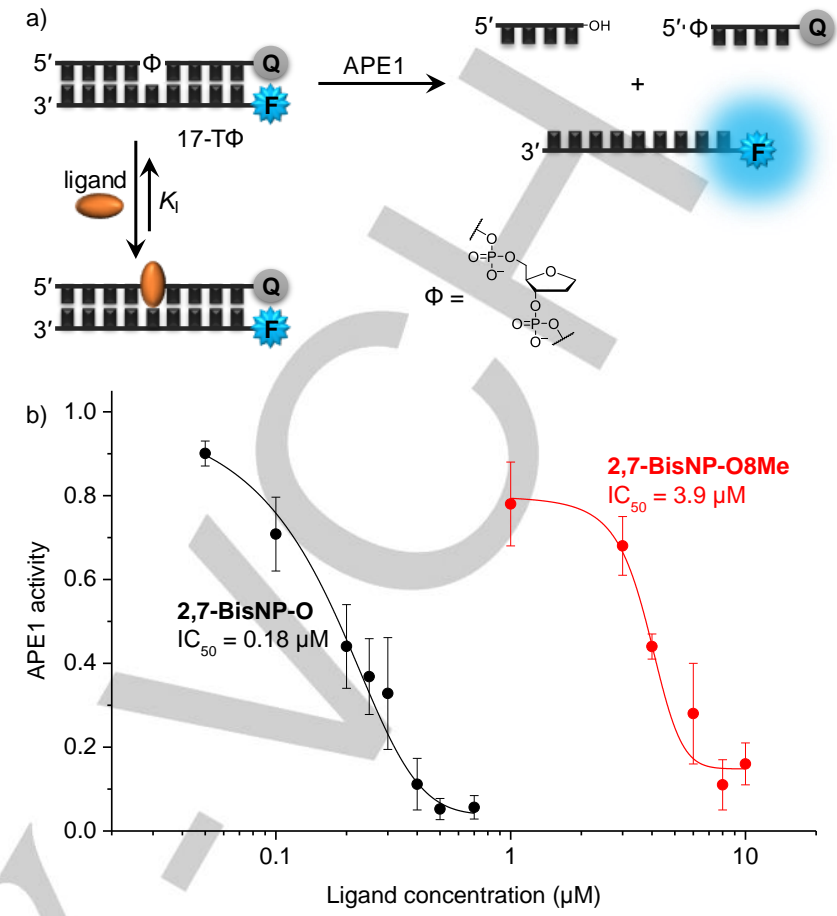

Figure 4. Inhibition of APE1 activity by AP-site ligands. a) Principle of the realtime fluorimetric assay for APE1 activity and indirect inhibition of APE1 by ligands binding to AP-sites. $F=A T T O 390, Q=D A B C Y L, \Phi=$ THF abasic site. b) Representative dose-response plots for APE1 inhibition by 2,7-BisNP-O (black) and 2,7-BisNP-O8Me (red). Conditions: $c(17-T \Phi)=0.2 \mu \mathrm{M}$ in $50 \mathrm{mM}$ HEPES, $50 \mathrm{mM} \mathrm{NaCl}, 1 \mathrm{mM} \mathrm{MgCl}_{2}$, $2 \mathrm{mM}$ DTT buffer, $\mathrm{pH} 8.0, T=37^{\circ} \mathrm{C}$, $\lambda_{\mathrm{ex}}=395 \mathrm{~nm}, \lambda_{\mathrm{em}}=465 \mathrm{~nm}$.

Table 2. Inhibitory activity of macrocyclic ligands with respect to APE1induced cleavage of $17-T \Phi$. [a]

\begin{tabular}{lll}
\hline Ligand & $\mathrm{IC}_{50} / \mu \mathrm{M}$ & $K_{\mathrm{l}} / \mathrm{nM}$ \\
\hline 2,7-BisNP-NH & 0.19 & 52 \\
2,7-BisNP-O & 0.18 & 50 \\
2,7-BisNP-S & 55 & 15000 \\
2,7-BisNP-NMe & 0.19 & 52 \\
2,7-BisNP-NNH & 0.14 & 39 \\
2,7-BisNP-NOH & 0.46 & 130 \\
2,7-BisNP-O4Me & 89 & 25000 \\
2,7-BisNP-O8Me & 3.9 & 1100 \\
2,7-BisNP-O4Gua & 0.4 & 110 \\
2,7-BisNP-Im & 2.0 & 550 \\
1,5-BisNP-O & 2.6 & 720 \\
2,7-TrisNP & 0.28 & 77 \\
\hline
\end{tabular}

[a] Conditions: see Figure 4 caption. 
Remarkably, a good correlation could be observed between the $1 / K_{1}$ values (i.e., affinity constants) and the ligand-induced stabilization of the substrate $\left(\Delta T_{\mathrm{m}}{ }^{\top \Phi}\right)$ observed in the presence of excess competitor $\left(r^{2}=0.72\right.$, Figure $\left.5 \mathrm{a}\right)$ : in other words, potent and selective AP-site ligands, whose stabilizing effect was not depressed by the presence of the competitor (2,7-BisNP-NNH $\mathbf{N N}_{2}$ 2,7-BisNP-NH, 2,7-BisNP-O, 2,7-BisNP-NMe), were most efficient at inhibiting the APE1-induced cleavage of AP-sites. A correlation made using $\Delta T_{\mathrm{m}}{ }^{\top \Phi}$ values obtained in the absence of the competitor was unsatisfactory $\left(r^{2}=0.26\right.$, Figure $\left.5 b\right)$ due to the fact that the stabilization induced by non-selective binders (e.g., 1,5-BisNP-O) was strongly reduced in the presence of the competitor. Altogether, the comparison made with a series of different ligands, varying in terms of their affinity and selectivity to AP-sites, convincingly support the indirect inhibition model and highlight the efficiency of DNA-targeted inhibition of DNA repair. Moreover, the revealed interplay between the affinity and the selectivity of DNA-targeting inhibitors is of utmost importance for their application in the cellular context, where DNA damage sites are disseminated throughout the large excess of undamaged genome.
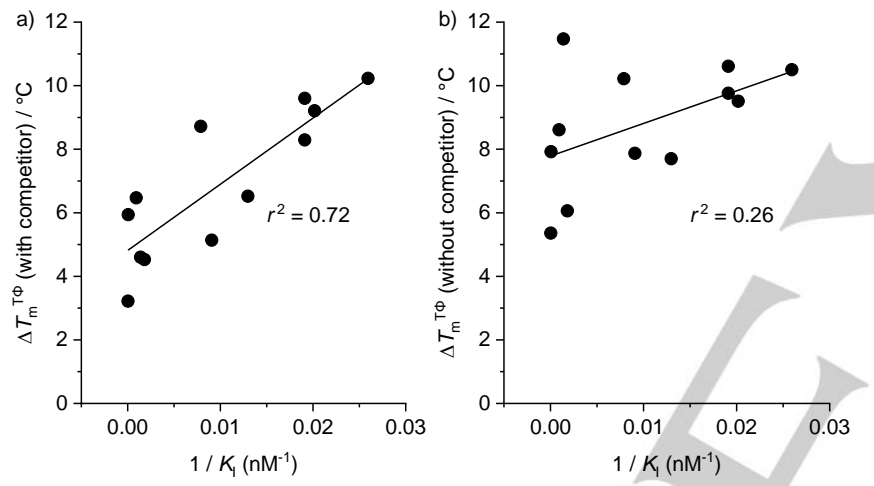

Figure 5. Correlation of ligand affinity constants to AP-sites, derived from APE1-inhibition studies interpreted in terms of indirect inhibition model ( $K_{\mathrm{a}}=$ $1 / K_{\mathrm{I}}$ ) with ligand-induced stabilization of 17-TФ observed a) in the absence and $b$ ) in the presence of competitor (ct DNA, $65 \mu \mathrm{M}$ bp).

\section{Intrinsic AP-DNA cleavage activity of ligands}

The intrinsic activity of ligands with respect to nucleophilecatalyzed cleavage of AP-sites was also assessed by means of a real-time fluorimetric assay, similar to the one developed by Berthet et al. ${ }^{[46]}$ Our variant of this assay employs the 17-mer duplex 17-TX (Table 1), double-labelled with ATTO390 and DABCYL and bearing a native abasic site $(X)$, quantitatively produced by UDG treatment of the corresponding uracilcontaining precursor 17-TU (Supporting Information, Figure S3). As in the APE1 activity assay, the progress of ligand-induced DNA cleavage is monitored through an increase of fluorescence, taking place upon dehybridization of the cleaved strand (Figure $6 a)$. In order to compensate for the partial ligand-induced fluorophore quenching, the extent of this effect was measured in control experiments with a non-cleavable substrate (17-TФ) and quantified as a ratio of fluorescence intensity in the presence and in the absence of ligands, used at identical concentration of
$5 \mu \mathrm{M}(Q F$, Table 2). This factor was taken into account for calculation of corrected initial reaction rates ( $v_{\text {corr }}$, Table 3$)$, used as quantitative indicators of AP-DNA cleavage activity of ligands $\left(v_{\text {corr }}=v_{0} / Q F\right.$, where $v_{0}$ are the initial slopes of real-time fluorescence intensity plots, Figure $6 \mathrm{~b}$ ).

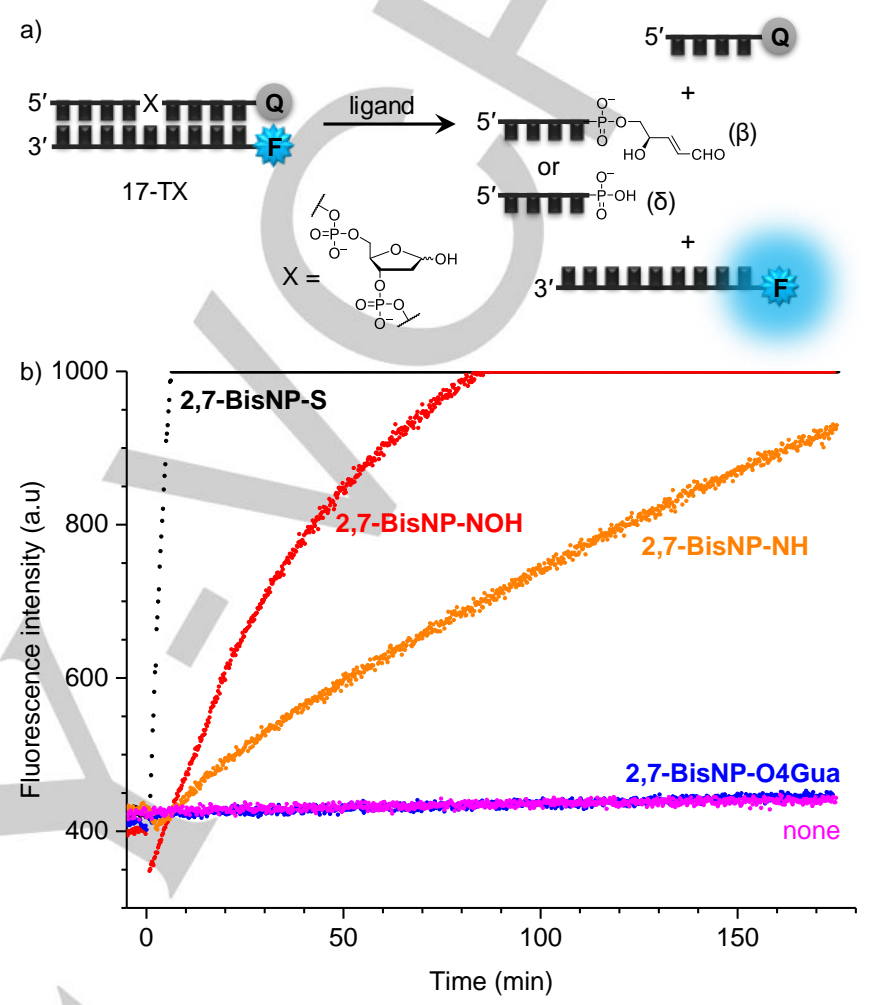

Figure 6. Real-time fluorimetric assay for determination of AP-DNA cleavage activity of ligands. a) Principle of the assay $(F=A T T O 390, Q=D A B C Y L, X=$ native abasic site). b) Representative fluorimetric readout for cleavage of 17 TX with 2,7-BisNP-NH, 2,7-BisNP-S, 2,7-BisNP-NOH and 2,7-BisNP-O4Gua. Conditions: $c(17-\mathrm{TX})=0.2 \mu \mathrm{M}, c$ (ligand) $=5 \mu \mathrm{M}$ in $10 \mathrm{mM} \mathrm{KAsO}_{2} \mathrm{Me}_{2}, 150 \mathrm{mM}$ $\mathrm{KCl}$ buffer, $\mathrm{pH} 7.2, T=37^{\circ} \mathrm{C}, \lambda_{\mathrm{ex}}=395 \mathrm{~nm}, \lambda_{\mathrm{em}}=465 \mathrm{~nm}$; the ligand was added at $t=0$. The transient drop of fluorescence intensity after ligand addition (red curve) is due to the ligand-induced quenching effect. The scale of fluorescence intensity (max value $=1000$ a.u.) was adjusted in order to allow the best comparison of initial reaction rates induced by different ligands.

In parallel, we assessed the DNA-cleavage activity of ligands through PAGE analysis using the duplex 17-TX, in which the AP strand was $5^{\prime}-{ }^{32} \mathrm{P}$-labelled. This complementary assay, performed in the conditions similar to the ones of the fluorimetric assay (with a fixed incubation time of $1 \mathrm{~h}$ ), avoids the problems related to the use of fluorescently labeled DNA (ligand-induced quenching) and, in addition, allows to estimate the distribution of various products of strand cleavage ( $\beta$ - and $\beta, \delta$-elimination products) and secondary reactions. Based on the results of the real-time fluorimetric assay (Table 3 ) and the PAGE assay (Figure 7), all ligands could be divided into three groups with respect to their AP-site cleavage activity: 
Table 3. DNA AP-site cleavage activity of macrocycles and reference ligands, measured by the real-time fluorimetric assay. ${ }^{[a]}$

\begin{tabular}{llll}
\hline Compound & $v_{0} /$ a.u. $\mathrm{s}^{-1}[\mathrm{~b}]$ & $Q F^{[\mathrm{c}]}$ & $v_{\text {corr }} /$ a.u. $\mathrm{s}^{-1}[\mathrm{~d}]$ \\
\hline 2,7-BisNP-NH & $3.02 \pm 0.16$ & 0.97 & 3.13 \\
2,7-BisNP-O & $5.64 \pm 0.34$ & 0.89 & 6.35 \\
2,7-BisNP-S & $115.92 \pm 5.87$ & 0.75 & 155 \\
2,7-BisNP-NMe & $4.29 \pm 0.44$ & 0.90 & 4.76 \\
2,7-BisNP-NNH & $33.00 \pm 1.23$ & 0.95 & 34.9 \\
2,7-BisNP-NOH & $12.85 \pm 0.65$ & 0.78 & 16.5 \\
2,7-BisNP-O4Me & $1.08 \pm 0.08$ & 0.91 & 1.19 \\
2,7-BisNP-O8Me & $0.16 \pm 0.02$ & 0.79 & 0.20 \\
2,7-BisNP-O4Gua & $0.31 \pm 0.19$ & 0.85 & 0.36 \\
2,7-BisNP-Im & $0.14 \pm 0.05$ & 0.54 & 0.25 \\
1,5-BisNP-O & $8.57 \pm 0.15$ & 0.73 & 11.8 \\
2,7-TrisNP & $0.09 \pm 0.01$ & 0.28 & 0.31 \\
KWKK & $0.17 \pm 0.02$ & 0.97 & 0.17 \\
spermine $\times$ 4 HCl & $1.31 \pm 0.11$ & 1.04 & 1.25 \\
no ligand & $0.10 \pm 0.00$ & & 0.10 \\
\hline
\end{tabular}

[a] Substrate: 17-TX ( $F=$ ATTO390. $Q=D A B C Y L)$, conditions: see Figure 6 legend. [b] Initial slope of the real-time fluorescence intensity plot (mean \pm s.d. from three technical replicates). [c] Ligand-induced fluorescence quenching of substrate, $Q F=F_{\text {with ligand }} / F_{\text {no ligand, }}$, measured with the non-cleavable analogue 17-T $\Phi$ at $c$ (ligand) $=5 \mu \mathrm{M}$. [d] Quenching-adjusted initial rate of AP-DNA cleavage reaction.

1) Very efficient AP-cleaving ligands, namely 2,7-BisNP-S $\left(v_{\text {corr }}=155\right.$ a.u. $\left.\mathrm{s}^{-1}\right)$ and 2,7-BisNP-NNH ${ }_{2}\left(v_{\text {corr }}=34.9\right.$ a.u. $\left.\mathrm{s}^{-1}\right)$, for which a total conversion of the substrate was observed after 1 hour, with the products of $\beta$ - and $\beta, \delta$ elimination forming in approximately $2: 1$ ratio (according to PAGE analysis). The high efficiency of 2,7-BisNP- $\mathrm{NNH}_{2}$ is, expectedly, due to the presence of two additional primary amino groups, which lead to an 11 -fold higher cleavage rate with respect to the parent ligand 2,7-BisNP-NH ( $v_{\text {corr }}=3.11$ a.u. $\left.\mathrm{s}^{-1}\right)$. The exceptionally high activity of the sulfurcontaining macrocycle is particularly remarkable, taking into account the fact that its affinity for AP sites is significantly lower than the one of 2,7-BisNP-NH and 2,7-BisNP-NNH $\mathbf{N}_{2}$, as demonstrated by both fluorescence-melting experiments (Figure 3) and APE1 inhibition studies (Table 2).

2) Moderately efficient AP-cleaving ligands $\left(2<v_{\text {corr }}<\right.$ 20 a.u. $\mathrm{s}^{-1}$ ): 2,7-BisNP-NH, 2,7-BisNP-NMe, 2,7-BisNPNOH, 2,7-BisNP-O and 1,5-BisNP-O, which induced from $\sim 60$ to $\sim 90 \%$ conversion of the substrate after $1 \mathrm{~h}$ (as determined by PAGE), giving predominantly $\beta$-elimination products $(\beta: \delta=4.5$ to 8 ). Only one ligand, 2,7-TrisNP, showed a discrepancy between the two methods: strong cleavage activity was detected by the PAGE assay (conversion $=89 \%$ after $1 \mathrm{~h}$ ), but not in the fluorimetric assay, presumably due to its strong quenching effect $(Q F=0.28)$.
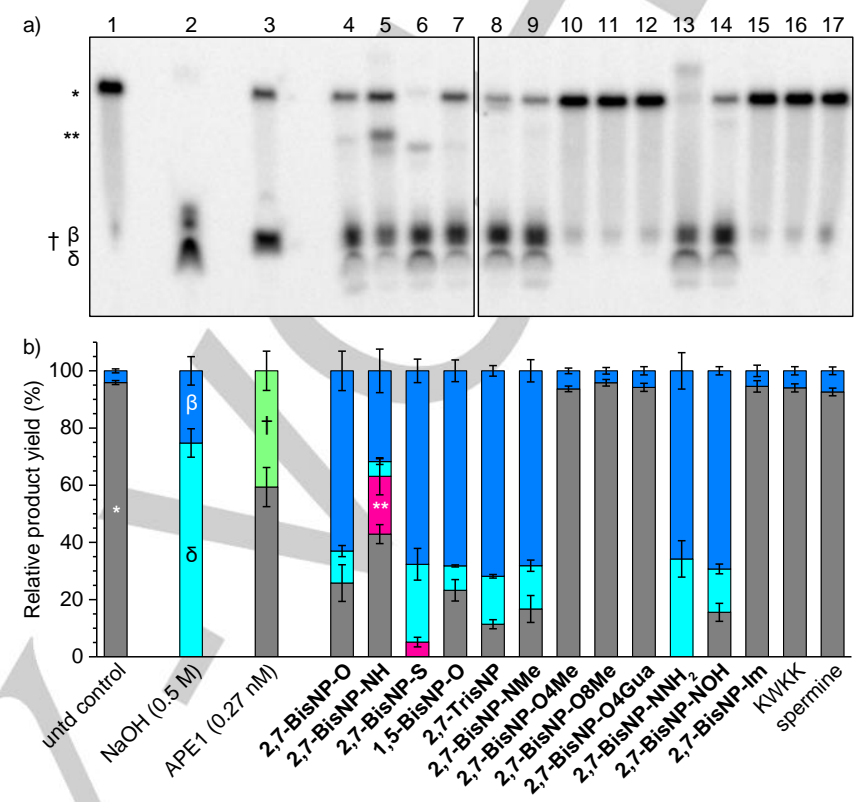

Figure 7. AP-site cleavage activity of ligands assessed by PAGE. a) PAGE analysis of ${ }^{32} \mathrm{P}$-labelled $17-\mathrm{TX}$ following incubation with ligands. Lane assignment: 1) untreated control; 2) $\mathrm{NaOH}$ treatment (0.5 M); 3) APE1 (0.27 $\mathrm{nM}$ ); 4) 2,7-BisNP-O; 5) 2,7-BisNP-NH; 6) 2,7-BisNP-S; 7) 1,5-BisNP-O; 8) 2,7-TrisNP; 9) 2,7-BisNP-NMe; 10) 2,7-BisNP-O4Me; 11) 2,7-BisNP-O8Me; 12) 2,7-BisNP-O4Gua; 13) 2,7-BisNP-NNH ${ }_{2}$; 14) 2,7-BisNP-NOH; 15) 2,7BisNP-Im; 16) KWKK; 17) spermine. Conditions: $c(17-\mathrm{TX})=0.2 \mu \mathrm{M}, c($ ligand) $=5 \mu \mathrm{M}$, incubation for $1 \mathrm{~h}$ in $10 \mathrm{mM} \mathrm{KAsO} \mathrm{Me}_{2}, 150 \mathrm{mM} \mathrm{KCl}$ buffer, $\mathrm{pH} 7.2$, $T=37^{\circ} \mathrm{C}$. Left and right panels are parts of the same gel. b) Quantification of PAGE data (means \pm s.d. from three technical replicates). Band assignment / color codes: * / grey, uncleaved substrate; $\beta$ / blue, product of $\beta$-elimination; $\delta$ / cyan, product of $\beta, \delta$-elimination; $\dagger$ / green, $3^{\prime}-\mathrm{OH}$ product of APE1 cleavage; ** / pink, putative ligand cross-link.

3) Mostly inactive ligands $\left(v_{\text {corr }}<2\right.$ a.u. $\mathrm{s}^{-1},<10 \%$ substrate conversion in PAGE assay): 2,7-BisNP-O4Me, 2,7-BisNPO8Me, 2,7-BisNP-O4Gua, 2,7-BisNP-Im, spermine and KWKK. Although spermine and the tetrapeptide KWKK are well-established AP-DNA cleaving agents, in both of our assays their activity was only marginal, likely due to at least 100 -fold lower concentration, comparing with previous works. ${ }^{[29,47]}$ This is also in line with the negligible AP-site binding effect of KWKK observed in FRET-melting experiments (Figure 3 ).

These results clearly demonstrate the influence of molecular structure of naphthalenophanes on their AP-DNA cleavage activity. Specifically, introduction of side chains at central nitrogen atoms of linkers results in enhanced cleavage activity (2,7-BisNP-NMe, 2,7-BisNP-NOH and, particularly, 2,7-BisNP$\mathrm{NNH}_{2}$ ) compared to 2,7-BisNP-NH. Conversely, suppression of nucleophilic centers through introduction of substituents at benzylic amino groups (2,7-BisNP-O8Me, 2,7-BisNP-O4Gua) or 
removal of these groups (2,7-BisNP-Im) totally abolishes the AP-DNA cleavage activity. In the last series, the derivative 2,7BisNP-O4Me represents an intermediate case: despite the presence of four tertiary, putatively nucleophilic, amino groups, the AP-DNA cleavage activity of this ligand is strongly reduced with respect to 2,7-BisNP-NH ( $v_{\text {corr }}=1.19$ a.u. $\mathrm{s}^{-1}$, conversion = $6 \%$ ). This behavior is likely due to the combination of two phenomena, namely: (i) the tertiary amino groups do not allow the formation of the pre-incision iminium intermediate of the $\beta$ elimination reaction (cf. Scheme 1); (ii) the AP-DNA affinity of 2,7-BisNP-O4Me is reduced with respect to the other ligands of the series (cf. Figure 3 and Table 2). Notably, a similar decrease of affinity and DNA-cleaving activity upon mono-methylation of secondary amino groups was observed in the series of nucleobase-polyamine-intercalator conjugates. ${ }^{[17]}$

\section{Formation of covalent adducts with abasic sites}

The results of PAGE analysis revealed that, in some cases, the formation of expected products of AP-site cleavage ( $\beta$ - and $\beta, \delta$ elimination products) was accompanied by appearance of novel bands of intermediate mobility ( ${ }^{* *}$ in Figure 7). These bands were observed mostly with 2,7-BisNP-NH (20\% yield, lane 5 ), but trace amounts could also be detected with 2,7-BisNP-S $(5 \%)$ and 2,7-BisNP-O (< 1\%). In order to get insight into the nature of these products, we performed several complementary studies. Incubation of 2,7-BisNP-NH with a DNA substrate devoid of abasic site (17-TU) gave no evidence of strand cleavage (Figure 8a, lanes 6-7), therefore excluding the possibility of a strand cleavage at a secondary site (i.e., away from the AP site). Furthermore, the product was stable towards a brief heating at $90{ }^{\circ} \mathrm{C}$ (Figure 8a, lane 4), which speaks in favor of a covalent modification of DNA. Next, we performed a trapping reaction through incubation of 17-TX with 2,7-BisNP$\mathrm{NH}$ in the conditions of reductive amination $\left(\mathrm{NaCNBH}_{3}\right.$, followed by $\mathrm{NaBH}_{4}$ quenching; Figure $8 \mathrm{a}$, lane 5). ${ }^{[29,33]}$ In this case, we evidenced the formation of a slower-migrating band ( ${ }^{* *}$ in Figure 8a), supposedly corresponding to the reduced preincision iminium base intermediate (cf. Scheme 1), as well as another band which migrated closely to the ** band and which could be attributed to the reduced post-incision intermediate (i.e. the product of reductive amination reaction of the polyamine with the $\alpha, \beta$-unsaturated aldehyde). ${ }^{[29,48]}$ Taking into account these results, we may suggest that the ** band in lanes $3-4$ (Figure $8 \mathrm{a})$, formed in the absence of reducing agents, corresponds to a stable but unreduced covalent adduct of the ligand with its own product of AP-site cleavage via $\beta$-elimination. In addition, its greatly retarded migration with respect to the other cleavage products is consistent with the partial charge neutralization of the oligonucleotide imparted by the remnant of the polycationic ligand (3 to 4 positive charges).

In a separate experiment, we examined the influence of reaction time on the formation of this product. The adduct yield increased with time and reached its maximum ( $60 \%)$ after $5 \mathrm{~h}$ of incubation at $37^{\circ} \mathrm{C}$, when all substrate was consumed (Figure $8 \mathrm{~b}, \mathrm{c})$. Notably, the increase of the amount of the DNA-ligand adduct was accompanied by a decrease of the yield of the $\beta$ elimination product at longer incubation time (from $30 \%$ after $1 \mathrm{~h}$ to $18 \%$ after $5 \mathrm{~h}$ of incubation), giving evidence that the $\beta$ elimination product represents an intermediate for the formation of the covalent adduct (and not vice versa)
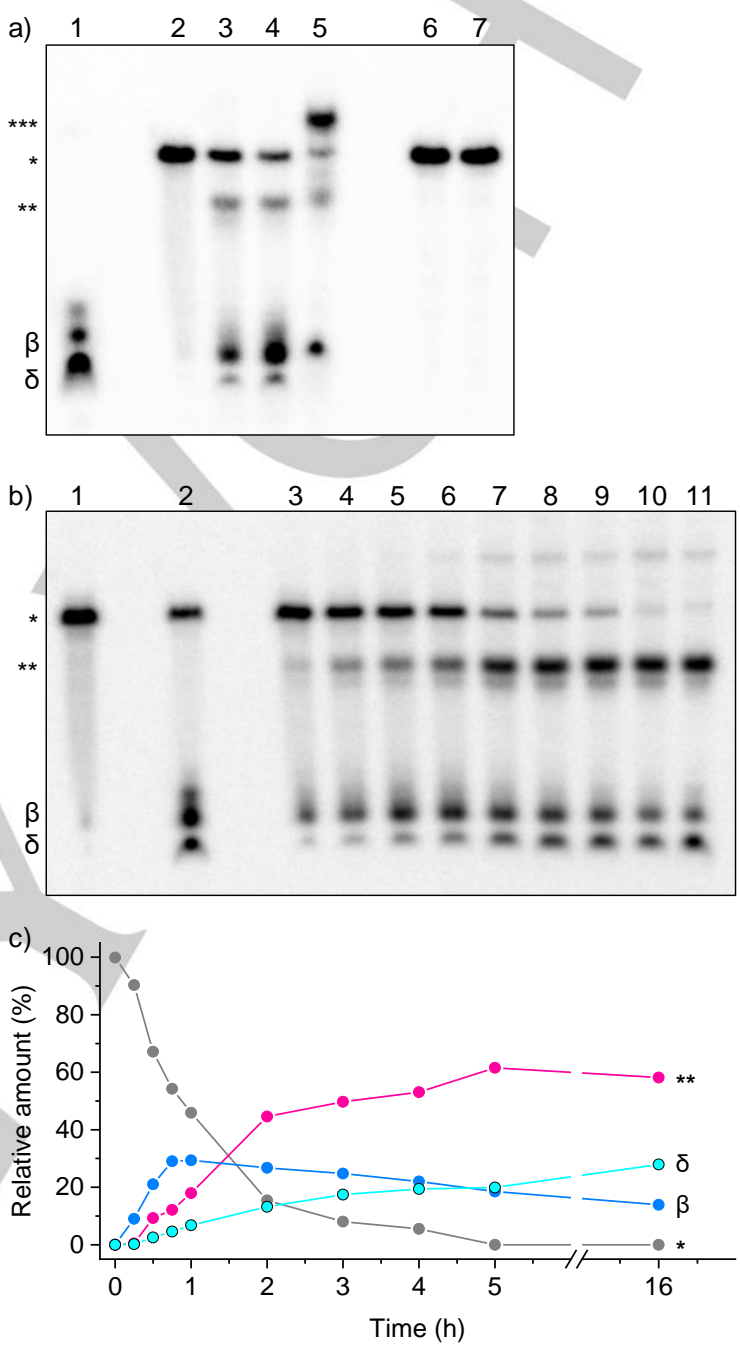

Figure 8. Formation of a covalent adduct of 2,7-BisNP-NH with abasic sites. a) PAGE analysis showing formation of slow-migrating bands of 2,7-BisNPNH upon incubation with 17-TX. Lane assignment: 1) 17-TX incubated with 0.5 $\mathrm{M} \mathrm{NaOH}(1 \mathrm{~h})$; 2) untreated 17-TX; 3) 17-TX incubated with 2,7-BisNP-NH $(5 \mu \mathrm{M})$; 4) same, but heated at $90^{\circ} \mathrm{C}(5 \mathrm{~min})$ prior to PAGE analysis, 5) 17-TX incubated with 2,7-BisNP-NH $(5 \mu \mathrm{M})$ and $\mathrm{NaCNBH}_{3}(25 \mathrm{mM})$, followed by addition of $\mathrm{NaBH}_{4}(100 \mathrm{mM})$ prior to PAGE analysis; 6$)$ untreated 17-TU; 7) 17-TU incubated in the presence of 2,7-BisNP-NH $(5 \mu \mathrm{M})$. b) Time dependence of the formation of covalent adduct. Lane assignment: 1) 17-TX incubated without additives for $16 \mathrm{~h}$; 2) $17-\mathrm{TX}$ incubated with $0.05 \mathrm{M} \mathrm{NaOH}$ (1 h); 3-11) 17-TX incubated with 2,7-BisNP-NH for $1 / 4,1 / 2,3 / 4,1,2,3,4,5$ and $16 \mathrm{~h}$, respectively. In all experiments, $c(17-\mathrm{TX})=0.2 \mu \mathrm{M}$. Band assignment: *, unmodified substrate; ${ }^{\star *}$, covalent ligand-DNA adduct; ${ }^{\star * *}$, reduced imine intermediate (lane 5), $\beta$, product of $\beta$-elimination (or its reduced form in lane $5)$; $\delta$, product of $\beta, \delta$-elimination. c) Quantification of PAGE shown in panel b).

Finally, we attempted mass-spectrometric characterization of the product corresponding to the ${ }^{* *}$ band observed in PAGE. A crude reaction mixture of 17-TX with 2,7-BisNP-NH was concentrated, desalted (EtOH precipitation followed by reversesolid-phase extraction), and analyzed by LC/MS (Figure 9a). 
Along with an unresolved peak containing cleavage products and the complementary strand, we observed a minor peak with a higher retention time $\left(t_{R}=4.05 \mathrm{~min}\right)$, consistent with the more lipophilic character imparted by the presence of the naphthalenophane remnant. A corresponding mass spectrum (Figure 9b) revealed the presence of two molecular ion peaks $(\mathrm{m} / \mathrm{z}=$ 1036 and 1555), which could indeed correspond to adduct of the ligand with the $\beta$-elimination product of DNA cleavage $(M=$ $3111 \mathrm{Da}$ ). Although the structure of this product could not be established unambiguously at this stage, we may suggest that it could be formed through a 1,4-conjugate addition of the neighboring amino group of the macrocyclic ligand to the post-incision iminium intermediate (cf. Scheme 1) leading to formation of a cyclic 1,4-diazepine (Figure 9c), which may be subjected to further isomerization. This hypothesis explains the fact that, among all ligands, only 2,7-BisNP-NH (presenting a 1,2-diamino fragment) gives substantial yield of the covalent adduct.
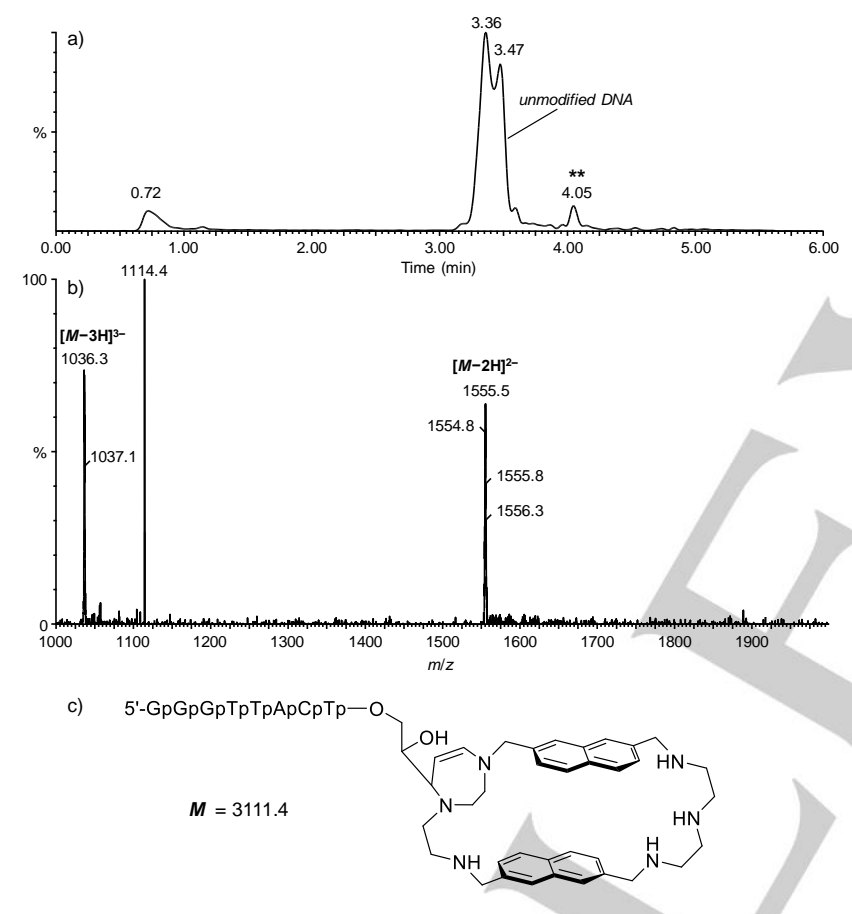

Figure 9. a) TIC chromatogram of the crude reaction mixture of 17-TX $(0.2 \mu \mathrm{M})$ with 2,7-BisNP-NH $(50 \mu \mathrm{M})$ (see Experimental Section for details). b) Mass spectrum of the peak with $t_{R}=4.05 \mathrm{~min}\left(^{* \star}\right)$. The peak with $\mathrm{m} / \mathrm{z}=1114.4$ could not be assigned. c) Putative structure of the covalent adduct of 2,7BisNP-NH to the product of $\beta, \delta$-elimination.

While the reaction of $\beta$-elimination products of AP-site cleavage with external alkoxyamines is known and has been exploited for their quantitative detection, ${ }^{[49]}$ the formation of covalent adducts with 2,7-BisNP-NH represents, to the best of our knowledge, the first example of generation of stable adducts through reaction of cleaved AP-sites with polyamine ligands. In this context, it is interesting to mention the formation of stable interstrand cross-links through reaction of both uncleaved ${ }^{[50,51]}$ and cleaved ${ }^{[52]}$ AP-sites with purine residues observed in native (non-reducing) conditions. Notably, in the latter case, the formation of the cross-link was proposed to occur through a 1,4conjugate addition of $\mathrm{N} 1$ of a proximate adenine residue to the unsaturated aldehyde product of $\beta$-elimination cleavage, which is reminiscent to the mechanism proposed above.

\section{Conclusions}

In the present work, we systematically explored the 2,7-naphthalenophane scaffold as a versatile platform for the development of functionalized ligands interacting, in various ways, with APsites in DNA. We demonstrated that careful molecular engineering could be exploited to exacerbate or alleviate some of their biochemical properties, as summarized in Table 4. Specifically, among seven novel compounds based on this scaffold, most ligands conserved the high affinity to abasic sites and excellent selectivity with respect to well-matched DNA Furthermore, we demonstrated that most compounds were able to inhibit the APE1-induced cleavage of AP-sites in DNA by competing with the enzyme for binding to the substrate, and that the inhibitory activity (as characterized by $\mathrm{IC}_{50}$ and $K_{\mathrm{I}}$ values) is directly related to the affinity and selectivity of ligands to the substrate (i.e., abasic site). Beyond direct implications in the context of APE1-related chemoresistance, these conclusions may be extended to other DNA repair pathways whose DNA substrate may represent a target for small-molecule ligands, such as direct damage reversal[53] and mismatch repair. ${ }^{[54,55]}$

Table 4. Qualitative summary of AP-DNA-binding properties, APE1 inhibitory activity, and intrinsic reactivity of naphthalenophane macrocycles with respect to AP-sites in DNA.

\begin{tabular}{|c|c|c|c|c|c|}
\hline \multirow[t]{2}{*}{ Ligand } & \multicolumn{2}{|c|}{ AP-DNA binding } & \multirow{2}{*}{$\begin{array}{l}\text { APE1 } \\
\text { inhibi- } \\
\text { tion }^{[b]}\end{array}$} & \multirow{2}{*}{$\begin{array}{l}\text { AP-DNA } \\
\text { cleavage } \\
\text { activity }^{[c]}\end{array}$} & \multirow{2}{*}{$\begin{array}{l}\text { AP } \\
\text { cross- } \\
\text { linking }\end{array}$} \\
\hline & affinity $^{[a]}$ & select. & & & \\
\hline 2,7-BisNP-NH & +++ & ++ & +++ & + & ++ \\
\hline 2,7-BisNP-O & +++ & +++ & +++ & + & $\pm[d]$ \\
\hline 2,7-BisNP-S & ++ & + & + & +++ & $\pm^{[\mathrm{d}]}$ \\
\hline 2,7-BisNP-NMe & +++ & ++ & +++ & + & - \\
\hline 2,7-BisNP-NNH ${ }_{2}$ & +++ & +++ & +++ & ++ & - \\
\hline 2,7-BisNP-NOH & +++ & ++ & +++ & + & - \\
\hline 2,7-BisNP-O4Me & + & + & + & - & - \\
\hline 2,7-BisNP-O8Me & ++ & ++ & ++ & - & - \\
\hline 2,7-BisNP-O4Gua & ++ & ++ & +++ & - & - \\
\hline 2,7-BisNP-Im & + & ++ & ++ & - & - \\
\hline 1,5-BisNP-O & +++ & + & ++ & + & - \\
\hline 2,7-TrisNP & ++ & +++ & +++ & + & - \\
\hline
\end{tabular}

[a] $\Delta T_{\mathrm{m}}{ }^{\top \Phi}<6(+), 6$ to $9(++),>9{ }^{\circ} \mathrm{C}(+++)$. [b] $K_{\mathrm{l}}>2000(+), 200$ to $2000(++)$, $<200 \mathrm{nM}(+++)$. [c] As discussed in manuscript text. [d] Traces. 
We also demonstrated that deliberate incorporation of substituents into the naphthalenophane scaffold may be exploited in order to modulate, or totally suppress, the intrinsic AP-site cleavage activity of ligands ( $\beta$ - and $\beta, \delta$-elimination reactions at AP-sites). Quite unexpectedly, most efficient AP-site cleavage was observed with the unsubstituted dithiaazamacrocycle 2,7-BisNP-S, followed by the rationally designed ligand endowed with two auxiliary nucleophilic groups, 2,7-BisNP$\mathrm{NNH}_{2}$. Even though the reasons of the particularly high activity of 2,7-BisNP-S are not clear at this point, this observation prompts for a further systematic and mechanistic study of sulfurcontaining DNA ligands as AP site-cleaving agents.

Last but not least, we demonstrated the formation of an unexpected covalent adduct upon reaction of at least one ligand, 2,7-BisNP-NH, with its own product of $\beta$-elimination cleavage at AP-sites. In analogy to other intrastrand and small-molecule cross-links of AP-sites, we expect this adduct to be genotoxic, representing a hurdle for DNA polymerases. ${ }^{[50,52,56]}$ It may also be potentially harnessed for covalent targeting of abasic sites and incorporation of reporter moieties, such as fluorophores or affinity tags for DNA pull-down studies.

Native AP sites are relatively stable in naked DNA, with a half-life of more than 3 weeks at $37^{\circ} \mathrm{C}$. However, AP sites embedded into chromatin undergo an up to 100 -fold accelerated cleavage via $\beta$-elimination mechanism, catalyzed by lysine-rich $\mathrm{N}$-terminal tails of histone proteins, as well as formation of persistent DNA-protein cross-links. ${ }^{[57-59]}$ In this context, masking AP sites with non-nucleophilic ligands (e.g., 2,7-BisNP-O4Gua and 2,7-BisNP-O8Me) may protect them not only from the APE1-induced hydrolysis, but also from $\beta$-elimination cleavage by histones and DNA lyases. Further studies will shed light on these aspects of AP reactivity.

\section{Experimental Section}

General remarks: All commercially available chemicals were reagent grade and used without further purification. NMR spectra were measured with a Bruker Avance $300\left({ }^{1} \mathrm{H}: 300 \mathrm{MHz},{ }^{13} \mathrm{C}: 75 \mathrm{MHz}\right)$ spectrometer at $25{ }^{\circ} \mathrm{C}$; chemical shifts are given in ppm $(\delta)$ values. Multiplicities of ${ }^{13} \mathrm{C}$ NMR signals were determined from DEPT-135 experiments. The melting points were determined in open-end capillaries with a digital melting point instrument (SMP30, Stuart). Elemental microanalysis of all novel compounds was performed by the Service de Microanalyse, CNRSICSN, Gif-sur-Yvette, France. Mass spectra (ESI in the positive-ion mode) were recorded with a Waters $Z Q$ instrument. The synthesis of naphthalenophanes 2,7-BisNP-NH $\times 6 \mathrm{HCl}, \mathbf{2 , 7 - B i s N P - O} \times 4 \mathrm{HCl}, \mathbf{2 , 7}-$ BisNP-S $\times 4 \mathrm{HCl}$, 1,5-BisNP-O $\times 4 \mathrm{HCl}^{[41]}$ and 2,7-TrisNP $\times 6 \mathrm{HCl}^{[60]}$ was described elsewhere. Tetrapeptide KWKK (hydrochloride salt) was purchased from Eurogentec. Ethidium bromide and spermine tetrahydrochloride were purchased from Sigma-Aldrich. Stock solution of ligands were prepared in water at a concentration of $2 \mathrm{mM}$ and stored at $4{ }^{\circ} \mathrm{C}$

\section{Synthesis}

2,7-Bis((imidazol-1-yl)methyl)naphthalene (2): To a solution of 2,7 bis(bromomethyl)naphthalene 1 (1.57 g, $5 \mathrm{mmol}$ ) in $\mathrm{MeOH}(100 \mathrm{~mL})$, imidazole $(3.4 \mathrm{~g}, 50 \mathrm{mmol})$ was added. The resulting mixture was heated under reflux for $22 \mathrm{~h}$. The solvent was evaporated under reduced pressure and aq. $\mathrm{K}_{2} \mathrm{CO}_{3}(6 \%, 100 \mathrm{~mL})$ was added. The yellow precipitate was collected and flash-chromatographed using gradient elution $\left(\mathrm{SiO}_{2}\right.$; eluent: 0 to $10 \% \mathrm{MeOH}$ in $\mathrm{CH}_{2} \mathrm{Cl}_{2}$ ), to give the product as a yellow powder (640 mg, $2.20 \mathrm{mmol}, 44 \%)$, m.p. $139-146^{\circ} \mathrm{C} .{ }^{1} \mathrm{H} \mathrm{NMR}(300 \mathrm{MHz}$, $\left.\mathrm{CDCl}_{3}\right): \delta 5.28(\mathrm{~s}, 2 \mathrm{H}), 6.94(\mathrm{~s}, 1 \mathrm{H}), 7.12(\mathrm{~s}, 1 \mathrm{H}), 7.29(\mathrm{~d}, 1 \mathrm{H}), 7.53(\mathrm{~s}$, $1 \mathrm{H}), 7.60(\mathrm{~s}, 1 \mathrm{H}), 7.83(\mathrm{~d}, 1 \mathrm{H}) ;{ }^{13} \mathrm{C}$ NMR $\left(75 \mathrm{MHz}, \mathrm{CDCl}_{3}\right): \delta 50.9\left(\mathrm{CH}_{2}\right)$ $125.5(\mathrm{CH}), 126.2(\mathrm{CH}), 128.8(\mathrm{CH}), 130.1(\mathrm{CH}), 132.6\left(\mathrm{C}_{\mathrm{q}}\right), 133.2\left(\mathrm{C}_{\mathrm{q}}\right)$, $134.7\left(\mathrm{C}_{\mathrm{q}}\right) ; \mathrm{MS}\left(\mathrm{ESI}^{+}\right): \mathrm{m} / \mathrm{z}(\%) 289.2(100)[\mathrm{M}+\mathrm{H}]^{+}$.

1,5(1,3)Diimidazolia-3,7(2,7)dinaphthalenacyclooctaphane dibromide (2,7-BisNP-Im, $2 \mathbf{B r}^{-}$): To a solution of compound 2 (157 mg, 0.54 $\mathrm{mmol}$ ) in acetonitrile (50 mL), 2,7-bis(bromomethyl)naphthalene 1 (171 $\mathrm{mg}, 0.54 \mathrm{mmol}$ ) was added. The resulting mixture was heated under reflux for $18 \mathrm{~h}$ and a white precipitate appeared. After cooling to room temperature, the precipitate was collected, washed with acetonitrile and ether, and recrystallized from $\mathrm{MeOH}-\mathrm{H}_{2} \mathrm{O}$ to give the product as a white solid (87.1 mg, $0.14 \mathrm{mmol}, 27 \%)$. ${ }^{1} \mathrm{H}$ NMR (300 MHz, [D6]DMSO): $\delta 5.76$ (s, 4H), $7.34(\mathrm{~s}, 2 \mathrm{H}), 7.66(\mathrm{~d}, J=8.4 \mathrm{~Hz}, 2 \mathrm{H}), 7.99(\mathrm{~s}, 2 \mathrm{H}), 8.05(\mathrm{~d}, J=$ $8.5 \mathrm{~Hz}, 2 \mathrm{H}), 9.53(\mathrm{~s}, 1 \mathrm{H}) ;{ }^{13} \mathrm{C}$ NMR $\left(75 \mathrm{MHz},\left[\mathrm{D}_{6}\right] \mathrm{DMSO}\right): \delta 51.8\left(\mathrm{CH}_{2}\right)$, $123.8(\mathrm{CH}), 124.1(\mathrm{CH}), 126.0(\mathrm{CH}), 128.5(\mathrm{CH}), 132.1\left(\mathrm{C}_{\mathrm{q}}\right), 133.0\left(\mathrm{C}_{\mathrm{q}}\right)$, $134.6\left(\mathrm{C}_{\mathrm{q}}\right), 137.8(\mathrm{CH})$; MS $\left(\mathrm{ESI}^{+}\right): \mathrm{m} / \mathrm{z}(\%): 441.0(12)\left[\mathrm{M}-\mathrm{H}^{+}, 221.2\right.$ (100) [M] ${ }^{2+}$; anal. calcd. for $\mathrm{C}_{30} \mathrm{H}_{26} \mathrm{Br}_{2} \mathrm{~N}_{4} \times 1.25 \mathrm{H}_{2} \mathrm{O}$ (624.88): C, 57.66; $\mathrm{H}$, 4.6; N, 8.97; found: C, 57.63; H, 4.39; N, 8.75.

Naphthalene-2,7-dicarbaldehyde (3): A solution of 2,7-bis(bromomethyl)naphthalene 1 (14.0 g, $44.5 \mathrm{mmol})$ and $\mathrm{NaHCO}_{3}(37.9 \mathrm{~g}, 451$ $\mathrm{mmol}$ ) in anhydrous DMSO $(125 \mathrm{~mL})$ was heated at $100^{\circ} \mathrm{C}$ during $3.5 \mathrm{~h}$ under argon atmosphere. The resulting mixture was cooled to room temperature, and water $(200 \mathrm{~mL})$ was added. The aqueous layer was extracted with ethyl acetate $(3 \times 230 \mathrm{~mL})$. The organic phases were combined, washed with water, dried with $\mathrm{MgSO}_{4}$, and the solvent was removed under reduced pressure. The residue was purified by flash chromatography $\left(\mathrm{SiO}_{2}\right.$; eluent: using 0 to $20 \%$ AcOEt in cyclohexane), to give the product as a light-yellow powder (4.63 g, $25.1 \mathrm{mmol}, 57 \%)$, m.p. 142-143 ${ }^{\circ} \mathrm{C}$ (lit. $\left.{ }^{[41]} 145-146{ }^{\circ} \mathrm{C}\right) .{ }^{1} \mathrm{H}$ NMR $\left(300 \mathrm{MHz}, \mathrm{CDCl}_{3}\right): \delta 8.03$ (d, J $=8.4 \mathrm{~Hz}, 2 \mathrm{H}), 8.13(\mathrm{dd}, J=8.6 \mathrm{~Hz}, 2 \mathrm{H}), 8.52(\mathrm{~s}, 2 \mathrm{H}), 10.22(\mathrm{~s}, 2 \mathrm{H})$; MS $\left(\mathrm{ESI}^{+}\right): m / z(\%) 185.1(100)[M+\mathrm{H}]^{+}$.

General procedure for the synthesis of macrocyclic tetraimine intermediates 4 and $5 \mathrm{a}-\mathrm{c}$ : A solution of the corresponding diamine (1.0 $\mathrm{mmol}$ ) in MeCN (60 mL; in the case of a poorly soluble $N, N$-bis(2-amino ethyl)aminopropan-1-ol (7), $4 \mathrm{~mL}$ of $\mathrm{MeOH}$ were used as a co-solvent) was added at room temperature dropwise, within $3 \mathrm{~h}$, to a vigorously stirred solution of $3(1.0 \mathrm{mmol})$ in $\mathrm{MeCN}(60 \mathrm{~mL})$. The reaction mixture was stirred at room temperature for 5-7 days. The formed precipitate was collected, washed with $\mathrm{MeCN}$ and dried in vacuo, to give the corresponding macrocyclic tetraimine $5 \mathrm{a}-\mathrm{c}$.

6,16-Dioxa-3,9,13,19-tetraaza-1,11(2,7)-dinaphthalenacycloicosaphane-2,9,12,19-tetraene (4) was obtained in a $91 \%$ yield through reaction of 3 with 1,5-diamino-3-oxapentane. White powder, ${ }^{1} \mathrm{H}$ NMR (300 MHz, $\left.\mathrm{CDCl}_{3}\right): \delta 3.78-3.88(\mathrm{~m}, 4 \mathrm{H}), 7.01(\mathrm{~s}, 1 \mathrm{H}), 7.68(\mathrm{~d}, J=8.5 \mathrm{~Hz}$, $1 \mathrm{H}), 7.98(\mathrm{~d}, J=8.5 \mathrm{~Hz}, 1 \mathrm{H}), 8.10(\mathrm{~s}, 1 \mathrm{H})$

6,16-Dimethyl-3,6,9,13,16,19-hexaaza-1,11(2,7)-dinaphthalenacycloicosaphane-2,9,12,19-tetraene (5a) was obtained in a $92 \%$ yield through reaction of 3 with $2,2^{\prime}$-diamino- $N$-methyldiethylamine. White powder, ${ }^{1} \mathrm{H} \mathrm{NMR}\left(300 \mathrm{MHZ}, \mathrm{CDCl}_{3}\right)$ : $\delta 2.34(\mathrm{~s}, 3 \mathrm{H}), 2.82(\mathrm{t}, 4 \mathrm{H}), 3.71(\mathrm{t}$ $4 \mathrm{H}), 6.82(\mathrm{~s}, 2 \mathrm{H}), 7.84(\mathrm{~d}, J=8.6 \mathrm{~Hz}, 2 \mathrm{H}), 8.09(\mathrm{~s}, 2 \mathrm{H}), 8.16(\mathrm{~d}, J=8.6$ $\mathrm{Hz}, 2 \mathrm{H})$.

6,16-Bis(3-(tert-butoxycarbonyl)aminopropyl)-3,6,9,13,16,19-hexaaza-1,11(2,7)-dinaphthalenacycloicosaphane-2,9,12, 19-tetraene (5b) 
was obtained in a $54 \%$ yield through reaction of 3 with tert-butyl $\mathrm{N}$-\{3[bis(2-aminoethyl)amino]propyl\}carbamate. [61] White powder, ${ }^{1} \mathrm{H}$ NMR $\left(300 \mathrm{MHz}, \mathrm{CDCl}_{3}\right): \delta 1.35(\mathrm{~s}, 18 \mathrm{H}), 1.55-1.57(\mathrm{~m}, 4 \mathrm{H}), 2.48(\mathrm{t}, 4 \mathrm{H}), 2.84$ $2.87(\mathrm{~m}, 8 \mathrm{H}), 3.04-3.06(\mathrm{~m}, 4 \mathrm{H}), 3.67$ (br s, 8H), 4.76 (br s, NH), 6.78 (s, $4 \mathrm{H}), 7.87(\mathrm{~d}, J=8.6 \mathrm{~Hz}, 4 \mathrm{H}), 8.07(\mathrm{~s}, 4 \mathrm{H}), 8.17(\mathrm{~d}, J=8.6 \mathrm{~Hz}, 4 \mathrm{H})$.

6,16-Bis(3-hydroxypropyl)-3,6,9,13,16,19-hexaaza-1,11(2,7)-dinaphthalenacycloicosaphane-2,9,12,19-tetraene (5c) was obtained in a $52 \%$ yield through reaction of 3 with $\mathrm{N}, \mathrm{N}$-bis(2-aminoethyl)aminopropan1-ol 7. Light-yellow powder, ${ }^{1} \mathrm{H}$ NMR $\left(300 \mathrm{MHz}, \mathrm{CDCl}_{3}\right)$ : $\delta$ 1.75-1.78 (m, $4 \mathrm{H}), 2.75-2.78(\mathrm{~m}, 4 \mathrm{H}), 2.89-2.91(\mathrm{~m}, 8 \mathrm{H}), 3.73(\mathrm{br} \mathrm{s}, 8 \mathrm{H}), 3.82-3.83(\mathrm{~m}$, $4 \mathrm{H}), 6.76(\mathrm{~s}, 4 \mathrm{H}), 7.77(\mathrm{~d}, J=8.3 \mathrm{~Hz}, 4 \mathrm{H}), 8.01-8.06(\mathrm{~m}, 8 \mathrm{H})$.

General procedure for the synthesis of polyazamacrocyles: To a suspension of the tetraimine intermediate $(0.18 \mathrm{mmol})$ in a mixture of $\mathrm{CH}_{2} \mathrm{Cl}_{2}(3.5 \mathrm{~mL})$ and $\mathrm{MeOH}(1.5 \mathrm{~mL}), \mathrm{NaBH}_{4}(104 \mathrm{mg}, 2.76 \mathrm{mmol})$ was added in one portion. The reaction mixture was stirred overnight at room temperature and the solvents were removed under reduced pressure. To the residue, aq. $\mathrm{NaOH}(1 \mathrm{M}, 30 \mathrm{~mL})$ was added, and the mixture was extracted with $\mathrm{CH}_{2} \mathrm{Cl}_{2}(3 \times 20 \mathrm{~mL})$. The combined organic layers were washed with saturated $\mathrm{K}_{2} \mathrm{CO}_{3}$ solution $(20 \mathrm{~mL})$, dried with anhyd. $\mathrm{K}_{2} \mathrm{CO}_{3}$ and evaporated in vacuo. The residue was flash-chromatographed using gradient elution with $\mathrm{NH}_{4} \mathrm{OH}\left(\mathrm{SiO}_{2}\right.$; eluent: $\mathrm{CH}_{2} \mathrm{Cl}_{2} / \mathrm{MeOH} /$ aq. $\mathrm{NH}_{4} \mathrm{OH}$, $80: 20: 2$ to $80: 20: 4)$, to give the macrocyclic polyamine as a free base. Novel macrocycles were fully characterized as hydrochloride salts.

\section{6,16-Dioxa-3,9,13,19-tetraaza-1,11(2,7)-dinaphthalenacycloicosa-} phane (2,7-BisNP-O) ${ }^{[41]}$ was obtained from 4 in a $88 \%$ yield. White powder, ${ }^{1} \mathrm{H}$ NMR (300 MHz, $\left.\mathrm{CDCl}_{3}\right)$ : $\delta 2.84(\mathrm{t}, J=5.0 \mathrm{~Hz}, 2 \mathrm{H}), 3.59$ (t, $2 \mathrm{H}), 3.90(\mathrm{~s}, 2 \mathrm{H}), 7.37(\mathrm{~d}, J=8.6 \mathrm{~Hz}, 1 \mathrm{H}), 7.63-7.65(\mathrm{~s}+\mathrm{d}, 2 \mathrm{H})$.

6,16-Bis(3-hydroxypropyl)-3,6,9,13,16,19-hexaaza-1,11(2,7)-dinaphthalenacycloicosaphane (2,7-BisNP-NOH) was obtained from $5 \mathrm{c}$ in a $28 \%$ yield. Yellow oil, ${ }^{1} \mathrm{H}$ NMR $\left(300 \mathrm{MHz}, \mathrm{CD}_{3} \mathrm{OD}\right): \delta 1.76$ (br s, $\left.2 \mathrm{H}\right)$, 2.70-2.76 (m, 6H), 2.92-2.96 (m, 4H), $3.62(\mathrm{t}, 2 \mathrm{H}), 3.90(\mathrm{~s}, 4 \mathrm{H}), 7.30$ $7.38(\mathrm{~m}, 2 \mathrm{H}), 7.43-7.48(\mathrm{~m}, 2 \mathrm{H}), 7.59-7.70(\mathrm{~m}, 2 \mathrm{H}) .2,7-\mathbf{B i s N P}-\mathbf{N O H} \times$ $6 \mathrm{HCl}$ : The free-base macrocycle $(31.9 \mathrm{mg}, 0.05 \mathrm{mmol})$ was dissolved in a mixture of $\mathrm{MeOH}$ and 1,4-dioxane $(2: 1,1.2 \mathrm{~mL})$. $\mathrm{HCl}(4 \mathrm{M}$ in 1,4dioxane, $0.25 \mathrm{~mL}$ ) was added, and the solution was stirred until the hydrochloride salt precipitated. The volatiles were removed under reduced pressure, to give 2,7-BisNP-NOH $\times 6 \mathbf{~ H C l}(30.8 \mathrm{mg}, 0.04 \mathrm{mmol}$, $71 \%)$ as a white powder. ${ }^{1} \mathrm{H}$ NMR $\left(300 \mathrm{MHz}, \mathrm{D}_{2} \mathrm{O}\right): \delta 1.63$ (quint, $2 \mathrm{H}$ ), $2.58(\mathrm{t}, 2 \mathrm{H}), 2.81(\mathrm{t}, J=5.3 \mathrm{~Hz}, 4 \mathrm{H}), 3.16(\mathrm{t}, J=5.8 \mathrm{~Hz}, 4 \mathrm{H}), 3.52(\mathrm{t}, J=$ $5.8 \mathrm{~Hz}, 2 \mathrm{H}), 4.17(\mathrm{~s}, 4 \mathrm{H}), 7.51(\mathrm{~d}, J=8.6 \mathrm{~Hz}, 2 \mathrm{H}), 7.89(\mathrm{~s}, 2 \mathrm{H}), 7.99(\mathrm{~d}, J$ $=8.6 \mathrm{~Hz}, 2 \mathrm{H}) ;{ }^{13} \mathrm{C}$ NMR $\left(75 \mathrm{MHz}, \mathrm{D}_{2} \mathrm{O}\right): \delta 26.0\left(\mathrm{CH}_{2}\right), 41.7\left(\mathrm{CH}_{2}\right), 48.5$ $\left(\mathrm{CH}_{2}\right), 50.8\left(\mathrm{CH}_{2}\right), 51.2\left(\mathrm{CH}_{2}\right), 58.8\left(\mathrm{CH}_{2}\right), 127.8(\mathrm{CH}), 128.2\left(\mathrm{C}_{\mathrm{q}}\right), 129.1$ (CH), $130.2(\mathrm{CH}), 132.3\left(\mathrm{C}_{\mathrm{q}}\right), 133.3\left(\mathrm{C}_{\mathrm{q}}\right)$; MS $\left(\mathrm{ESI}^{+}\right): \mathrm{m} / \mathrm{z}(\%) 627.5(40)$ $\left[M+\mathrm{H}^{+}\right.$; anal. calcd. for $\mathrm{C}_{38} \mathrm{H}_{60} \mathrm{Cl}_{6} \mathrm{~N}_{6} \mathrm{O}_{2} \times 3.8 \mathrm{H}_{2} \mathrm{O}(914.04): \mathrm{C}, 49.93 ; \mathrm{H}$ 7.45; N, 9.19; O, 10.15; found : C, 50.06, H, 7.16; N, 8.89; O, 9.88.

\section{6,16-Bis(3-(tert-butoxycarbonyl)aminopropyl)-3,6,9,13,16,19-hexa-} aza-1,11(2,7)-dinaphthalenacycloicosaphane (2,7-BisNP-NNHBoc) was obtained from $\mathbf{5 b}$ in a $67 \%$ yield. Colorless oil, ${ }^{1} \mathrm{H}$ NMR $(300 \mathrm{MHz}$, $\left.\mathrm{CDCl}_{3}\right): \delta 1.41(\mathrm{~s}, 9 \mathrm{H}), 1.66(\mathrm{br} \mathrm{s}, 2 \mathrm{H}), 2.40(\mathrm{t}, 2 \mathrm{H}), 2.52(\mathrm{t}, J=5.1 \mathrm{~Hz}$, $4 \mathrm{H}), 2.69(\mathrm{t}, J=5.1 \mathrm{~Hz}, 4 \mathrm{H}), 3.07-3.08(\mathrm{~m}, 2 \mathrm{H}), 3.86(\mathrm{~s}, 4 \mathrm{H}), 5.85(\mathrm{br} \mathrm{s}$, $\mathrm{NH}), 7.36(\mathrm{~d}, J=8.4 \mathrm{~Hz}, 2 \mathrm{H}), 7.47(\mathrm{~s}, 2 \mathrm{H}), 7.65(\mathrm{~d}, J=8.4 \mathrm{~Hz}, 2 \mathrm{H}) .2,7$ BisNP-NNH $\mathrm{NH}_{2} \times 8 \mathrm{HCl}$ : The free-base macrocycle $(149 \mathrm{mg}, 0.18 \mathrm{mmol})$ was dissolved in a mixture of $\mathrm{MeOH}$ and 1,4-dioxane (2:1, $4 \mathrm{~mL}) . \mathrm{HCl}(4$ $\mathrm{M}$ in 1,4-dioxane, $0.8 \mathrm{~mL}$ ) was added, and the solution was stirred until the hydrochloride salt precipitated. The volatiles were removed under reduced pressure, and the residue was purified by recrystallization from $\mathrm{EtOH}-\mathrm{H}_{2} \mathrm{O}$ to give $\mathbf{2 , 7}-\mathrm{BisNP}-\mathbf{N N H}_{2} \times \mathbf{8} \mathbf{H C l}$ as a white solid $(87.7 \mathrm{mg}$, $0.10 \mathrm{mmol}, 53 \%)$. ${ }^{1} \mathrm{H}$ NMR $\left(300 \mathrm{MHz}, \mathrm{D}_{2} \mathrm{O}\right): \delta 1.90-2.01(\mathrm{~m}, 2 \mathrm{H}), 2.90$ $3.03(\mathrm{~m}, 4 \mathrm{H}), 3.13(\mathrm{t}, J=6.4 \mathrm{~Hz}, 4 \mathrm{H}), 3.29(\mathrm{~m}, 4 \mathrm{H}), 4.22(\mathrm{~s}, 4 \mathrm{H}), 7.51(\mathrm{~d}$,
$J=8.5 \mathrm{~Hz}, 2 \mathrm{H}), 7.96-7.99(\mathrm{~s}+\mathrm{d}, 4 \mathrm{H}) ;{ }^{13} \mathrm{C}$ NMR $\left(75 \mathrm{MHz}, \mathrm{D}_{2} \mathrm{O}\right): \delta 22.0$ $\left(\mathrm{CH}_{2}\right), 37.0\left(\mathrm{CH}_{2}\right), 42.5\left(\mathrm{CH}_{2}\right), 48.2\left(\mathrm{CH}_{2}\right), 50.1\left(\mathrm{CH}_{2}\right), 50.7\left(\mathrm{CH}_{2}\right), 127.9$ $(\mathrm{CH}), 128.4\left(\mathrm{C}_{\mathrm{q}}\right), 129.2(\mathrm{CH}), 130.2(\mathrm{CH}), 132.4\left(\mathrm{C}_{\mathrm{q}}\right), 133.3\left(\mathrm{C}_{\mathrm{q}}\right)$; MS $\left(\mathrm{ESI}^{+}\right): \mathrm{m} / \mathrm{z}(\%) 625.7(65)\left[\mathrm{M}+\mathrm{H}^{+}\right.$; anal. calcd. for $\mathrm{C}_{38} \mathrm{H}_{64} \mathrm{Cl}_{8} \mathrm{~N}_{8} \times 4 \mathrm{H}_{2} \mathrm{O}$ (988.65): C, 46.17; H, 7.34; N, 11.33; found : C, 46.47; H, 7.15; N, 10.91.

6,16-Dimethyl-3,6,9,13,16,19-hexaaza-1,11(2,7)-dinaphthalenacycloicosaphane (2,7-BisNP-NMe) was obtained from 5 a in a $76 \%$ yield. White powder, ${ }^{1} \mathrm{H}$ NMR $\left(300 \mathrm{MHz}, \mathrm{CDCl}_{3}\right): \delta 2.20(\mathrm{~s}, 3 \mathrm{H}), 2.48(\mathrm{t}, 4 \mathrm{H}, J=$ $6.0 \mathrm{~Hz}$ ), 2.73 (t, $J=5.7 \mathrm{~Hz}, 4 \mathrm{H}), 3.86(\mathrm{~s}, 4 \mathrm{H}), 7.36$ (dd, $J=8.4 \mathrm{~Hz}, 2 \mathrm{H})$, $7.49(\mathrm{~s}, 2 \mathrm{H}), 7.60(\mathrm{~d}, J=8.4 \mathrm{~Hz}, 1 \mathrm{H}) .2,7-B i s N P-N M e \times 6 \mathrm{HCl}:$ The freebase macrocycle (269 mg, $0.5 \mathrm{mmol}$ ) was dissolved in a mixture of $\mathrm{MeOH}$ and 1,4-dioxane $(2: 1,15 \mathrm{~mL}) . \mathrm{HCl}(4 \mathrm{M}$ in 1,4-dioxane, $3.13 \mathrm{~mL})$ was added, and a precipitate has formed immediately. The volatiles were removed in vacuo, and the residue was recrystallized from $0.5 \mathrm{M}$ aq. $\mathrm{HCl}$ to give 2,7-BisNP-NMe $\times 6 \mathrm{HCl}(476 \mathrm{mg}, 0.58 \mathrm{mmol}$, quant. yield) as a colorless crystalline solid. ${ }^{1} \mathrm{H}$ NMR $\left(300 \mathrm{MHz}, 0.01 \mathrm{M} \mathrm{DCl}\right.$ in $\left.\mathrm{D}_{2} \mathrm{O}\right): \delta 2.88$ (s, 3H), $3.52(\mathrm{~s}, 8 \mathrm{H}), 4.47(\mathrm{~s}, 4 \mathrm{H}), 7.62(\mathrm{~d}, J=8.4 \mathrm{~Hz}, 2 \mathrm{H}), 8.06(\mathrm{~d}, J=$ $8.5 \mathrm{~Hz}, 2 \mathrm{H}), 8.10(\mathrm{~s}, 2 \mathrm{H}) ;{ }^{13} \mathrm{C}$ NMR $\left(75 \mathrm{MHz}, 0.01 \mathrm{M} \mathrm{DCl}\right.$ in $\left.\mathrm{D}_{2} \mathrm{O}\right): \delta 41.4$ $\left(\mathrm{CH}_{3}\right), 41.8\left(\mathrm{CH}_{2}\right), 51.9\left(\mathrm{CH}_{2}\right), 52.5\left(\mathrm{CH}_{2}\right), 128.5(\mathrm{CH}), 128.9\left(\mathrm{C}_{\mathrm{q}}\right), 129.9$ $(\mathrm{CH}), 130.9(\mathrm{CH}), 133.1\left(\mathrm{C}_{\mathrm{q}}\right), 134.1\left(\mathrm{C}_{\mathrm{q}}\right)$; MS $\left(\mathrm{ESI}^{+}\right): \mathrm{m} / \mathrm{z}(\%) 539.5(100)$ $[M+\mathrm{H}]^{+}$; anal. calcd. for $\mathrm{C}_{34} \mathrm{H}_{52} \mathrm{~N}_{6} \mathrm{Cl}_{6} \times 3.5 \mathrm{H}_{2} \mathrm{O}$ (820.6): C, 49.76; $\mathrm{H}$ $7.25 ; \mathrm{N}, 10.24$; found C, 49.60; H, 7.03; N, 10.24

3,9,13,19-Tetramethyl-6,16-dioxa-3,9,13,19-tetraaza-1,11(2,7)dinaphthalenacycloicosaphane (2,7-BisNP-O4Me): To a solution of 2,7BisNP-O (200 mg, $0.39 \mathrm{mmol})$ in $\mathrm{HCOOH}(0.82 \mathrm{~mL})$, aq. $\mathrm{HCHO}(37 \%$, $0.82 \mathrm{~mL}, 7.80 \mathrm{mmol}$ ) was added. The resulting mixture was heated at $120^{\circ} \mathrm{C}$ for $24 \mathrm{~h}$, evaporated under reduced pressure, and aq. $\mathrm{NaOH}(1 \mathrm{M}$, $40 \mathrm{~mL}$ ) was added. The aqueous layer was extracted with $\mathrm{CH}_{2} \mathrm{Cl}_{2}(3 \mathrm{x}$ $25 \mathrm{~mL}$ ), and the combined organic layers were dried with anhyd. $\mathrm{K}_{2} \mathrm{CO}_{3}$ and evaporated in vacuo. The residue was flash-chromatographed using gradient elution with $\mathrm{NH}_{4} \mathrm{OH}\left(\mathrm{SiO}_{2}\right.$; eluent: $\mathrm{CH}_{2} \mathrm{Cl}_{2} / \mathrm{MeOH} /$ aq. $\mathrm{NH}_{4} \mathrm{OH}$, $80: 20: 0$ to $80: 20: 2$ ), to give the product as a white solid (140 mg, $0.25 \mathrm{mmol}, 63 \%) .{ }^{1} \mathrm{H}$ NMR $\left(300 \mathrm{MHz}, \mathrm{CDCl}_{3}\right): \delta 2.28(\mathrm{~s}, 3 \mathrm{H}), 2.59(\mathrm{t}, J=$ $5.6 \mathrm{~Hz}, 2 \mathrm{H}), 3.52$ (t, $J=5.6 \mathrm{~Hz}, 2 \mathrm{H}), 3.63(\mathrm{~s}, 2 \mathrm{H}), 7.39(\mathrm{~d}, J=8.4 \mathrm{~Hz}, 1 \mathrm{H})$, 7.57 (s, $1 \mathrm{H}), 7.65(\mathrm{~d}, J=8.4 \mathrm{~Hz}, 1 \mathrm{H}) .2,7-B i s N P-04 \mathrm{Me} \times 4 \mathrm{HCl}$ : The free-base macrocycle $(281 \mathrm{mg}, 0.5 \mathrm{mmol})$ was dissolved in a mixture of $\mathrm{MeOH}$ and 1,4-dioxane (2:1, $10 \mathrm{~mL}) . \mathrm{HCl}$ (4 $\mathrm{M}$ in 1,4-dioxane, $2 \mathrm{~mL}$ ) was added and the solution was stirred until the hydrochloride salt precipitated. The volatiles were evaporated under reduced pressure, and the residue was purified by recrystallization from anhydrous isopropanol, to give the product $(214 \mathrm{mg}, 0.30 \mathrm{mmol}, 60 \%)$ as a white solid. ${ }^{1} \mathrm{H}$ NMR $\left(300 \mathrm{MHz}, \mathrm{D}_{2} \mathrm{O}, 60^{\circ} \mathrm{C}\right): \delta 3.23(\mathrm{~s}, 3 \mathrm{H}), 3.84(\mathrm{~m}, 2 \mathrm{H}), 4.26(\mathrm{~m}, 2 \mathrm{H}), 4.51$ $(\mathrm{m}, 2 \mathrm{H}), 7.65(\mathrm{~d}, J=8.0 \mathrm{~Hz}, 1 \mathrm{H}), 8.18(\mathrm{~s}, 1 \mathrm{H}), 8.23(\mathrm{~d}, J=8.5 \mathrm{~Hz}, 1 \mathrm{H})$ ${ }^{13} \mathrm{C}$ NMR $\left(75 \mathrm{MHz}, \mathrm{D}_{2} \mathrm{O}, 60{ }^{\circ} \mathrm{C}\right): \delta 41.7\left(\mathrm{CH}_{3}\right), 55.4\left(\mathrm{CH}_{2}\right), 61.1\left(\mathrm{CH}_{2}\right)$, $65.3\left(\mathrm{CH}_{2}\right), 128.0\left(\mathrm{C}_{\mathrm{q}}\right), 129.0(\mathrm{CH}), 129.5(\mathrm{CH}), 131.5(\mathrm{CH}), 132.6\left(\mathrm{C}_{\mathrm{q}}\right)$ $133.8\left(\mathrm{C}_{\mathrm{q}}\right)$; MS $\left(\mathrm{ESI}^{+}\right): \mathrm{m} / \mathrm{z}(\%) 569.5(100)[\mathrm{M}+\mathrm{H}]^{+}$; anal. calcd. for $\mathrm{C}_{36} \mathrm{H}_{52} \mathrm{~N}_{4} \mathrm{O}_{2} \mathrm{Cl}_{4} \times 1.5 \mathrm{H}_{2} \mathrm{O}(741.64): \mathrm{C}, 58.30 ; \mathrm{H}, 7.47 ; \mathrm{N}, 7.55$; found : C, 58.38; $\mathrm{H}, 7.41 ; \mathrm{N}, 7.31$.

3,3,9,9,13,13,19,19-Octamethyl-6,16-dioxa-3,9,13,19-tetraazonia-1,11 (2,7)-dinaphthalenacycloicosaphane iodide (2,7-BisNP-O-Me, $\left.4 \mathrm{I}^{-}\right)$: In a sealed tube, the macrocycle 2,7-BisNP-O (205 mg, $0.4 \mathrm{mmol})$, iodomethane $(2.00 \mathrm{~mL}, 4.54 \mathrm{~g}, 32 \mathrm{mmol})$ and DIPEA $(0.79 \mathrm{~mL}, 619 \mathrm{mg}$, $4.8 \mathrm{mmol})$ in DMF $(12 \mathrm{~mL})$ were stirred at $60^{\circ} \mathrm{C}$ for $24 \mathrm{~h}$. After cooling to room temperature, the precipitate was collected, washed with DMF, dried in vacuo, and recrystallized from water to give the product as a white solid (378 mg, $0.33 \mathrm{mmol}, 83 \%)$. ${ }^{1} \mathrm{H}$ NMR (300 MHz, [D6] DMSO:) $\delta 3.11$ $(\mathrm{s}, 12 \mathrm{H}), 3.67(\mathrm{~s}, 4 \mathrm{H}), 4.08(\mathrm{~s}, 4 \mathrm{H}), 4.80(\mathrm{~s}, 4 \mathrm{H}), 7.72(\mathrm{~d}, J=8.4 \mathrm{~Hz}, 2 \mathrm{H})$ $8.09(\mathrm{~d}, J=8.4 \mathrm{~Hz}, 2 \mathrm{H}), 8.34(\mathrm{~s}, 2 \mathrm{H}) ;{ }^{13} \mathrm{C}$ NMR $\left(75 \mathrm{MHz},\left[\mathrm{D}_{6}\right] \mathrm{DMSO}\right): \delta$ $50.2\left(\mathrm{CH}_{3}\right), 63.4\left(\mathrm{CH}_{2}\right), 64.1\left(\mathrm{CH}_{2}\right), 67.4\left(\mathrm{CH}_{2}\right), 126.2\left(\mathrm{C}_{\mathrm{q}}\right), 128.3(\mathrm{CH})$ $131.1(\mathrm{CH}), 131.9\left(\mathrm{C}_{\mathrm{q}}\right), 133.6(\mathrm{CH}), 134.1\left(\mathrm{C}_{\mathrm{q}}\right) ; \mathrm{MS}\left(\mathrm{ESI}^{+}\right): \mathrm{m} / \mathrm{z}(\%) 967.6$ (24) $\left[\mathrm{M}+3 \mathrm{CF}_{3} \mathrm{COO}^{-}\right]^{+}, 427.3(75)\left[\mathrm{M}+2 \mathrm{CF}_{3} \mathrm{COO}^{-}\right]^{2+}$; anal. calcd. for 
$\mathrm{C}_{40} \mathrm{H}_{60} \mathrm{~N}_{4} \mathrm{O}_{2} \mathrm{I}_{4} \times \mathrm{H}_{2} \mathrm{O}$ (1154.58): C, 41.61; $\mathrm{H}, 5.41 ; \mathrm{N}, 4.85$; found: $\mathrm{C}$, 41.77; H, 5.72; N, 4.48 .

3,9,13,19-Tetra(N,N'-bis(tert-butoxycarbonyl)carbamimidoyl)-6,16-dioxa-3,9,13,19-tetraaza-1,11(2,7)dinaphthalenacycloicosaphane (6): To a solution of 2,7-BisNP-O (512 mg, $1.0 \mathrm{mmol})$ in $\mathrm{CH}_{2} \mathrm{Cl}_{2}(50 \mathrm{~mL}), 1,3-$ bis(tert-butoxycarbonyl)-2-methyl-2-thiopseudourea (1.45 g, $5.0 \mathrm{mmol}$ ), $\mathrm{NEt}_{3}(2.78 \mathrm{~mL}, 20 \mathrm{mmol})$ and mercury(II) chloride $(1.36 \mathrm{~g}, 5 \mathrm{mmol})$ were added. The resulting mixture was stirred for 2 days at room temperature and then filtered through a bed of Celite. The filtrate was washed with water $(3 \times 50 \mathrm{~mL})$, brine $(50 \mathrm{~mL})$, dried with $\mathrm{MgSO}_{4}$ and evaporated in vacuo. The residue was flash-chromatographed using gradient elution ( $\mathrm{SiO}_{2}$; eluent: 0 to $10 \% \mathrm{MeOH}$ in $\mathrm{CH}_{2} \mathrm{Cl}_{2}$ ), to give the product as a white powder (1.24 g, $0.84 \mathrm{mmol}, 84 \%)$. ${ }^{1} \mathrm{H}$ NMR $\left(300 \mathrm{MHz}, \mathrm{CDCl}_{3}\right): \delta 1.51$ (s, $18 \mathrm{H}), 3.37$ (br s, 4H), $4.78(\mathrm{~s}, 2 \mathrm{H}), 7.37-7.46(\mathrm{~m}, 2 \mathrm{H}), 7.74(\mathrm{~d}, J=8.3 \mathrm{~Hz}$ $1 \mathrm{H}), 9.42$ (br s, NH); MS (ESI $): m / z(\%) 741.5(100)[M+2 H]^{2+}$

3,9,13,19-Tetra(carbamimidoyl)-6,16-dioxa-3,9,13,19-tetraaza-5,221,11(2,7)dinaphthalenacycloicosaphane hydrochloride (2,7-BisNPO4Gua $\times 4 \mathrm{HCl})$ : To a solution of compound $6(1.24 \mathrm{~g}, 0.839 \mathrm{mmol})$ in chloroform (4 mL), $\mathrm{HCl}$ (4 $\mathrm{M}$ in 1,4-dioxane, $4.20 \mathrm{~mL}, 16.8 \mathrm{mmol}$ ) was added, the resulting mixture was stirred at room temperature during $24 \mathrm{~h}$. The volatiles were evaporated in vacuo and the product was purified by two recrystallizations, first from $\mathrm{EtOH}$ and then from aq. $15 \% \mathrm{HCl}$, to give the product as white crystals $(270 \mathrm{mg}, 0.31 \mathrm{mmol}, 37 \%)$. ${ }^{1} \mathrm{H}$ NMR $(300$ $\left.\mathrm{MHz}, \mathrm{D}_{2} \mathrm{O}\right): \delta 3.53-3.54(\mathrm{~m}, 4 \mathrm{H}), 3.61-3.62(\mathrm{~m}, 4 \mathrm{H}), 4.66(\mathrm{~s}, 4 \mathrm{H}), 7.35(\mathrm{~d}$ $J=8.5 \mathrm{~Hz}, 2 \mathrm{H}), 7.44(\mathrm{~s}, 2 \mathrm{H}), 7.86(\mathrm{~d}, J=8.5 \mathrm{~Hz}, 2 \mathrm{H}) ;{ }^{13} \mathrm{C} \mathrm{NMR}(75 \mathrm{MHz}$, $\left.\mathrm{D}_{2} \mathrm{O}\right): \delta 50.7\left(\mathrm{CH}_{2}\right), 53.7\left(\mathrm{CH}_{2}\right), 69.0\left(\mathrm{CH}_{2}\right), 124.6(\mathrm{CH}), 125.5(\mathrm{CH})$, $129.4(\mathrm{CH}), 132.6\left(\mathrm{C}_{\mathrm{q}}\right), 133.4\left(\mathrm{C}_{\mathrm{q}}\right), 134.1\left(\mathrm{C}_{\mathrm{q}}\right), 157.9\left(\mathrm{C}_{\mathrm{q}}\right)$; $\mathrm{MS}\left(\mathrm{ESI}^{+}\right): \mathrm{m} / \mathrm{z}$ (\%) 681.5 (100) $\left[M+\mathrm{H}^{+}\right.$; anal. calcd. for $\mathrm{C}_{36} \mathrm{H}_{52} \mathrm{~N}_{12} \mathrm{O}_{2} \mathrm{Cl}_{4} \times 2.5 \mathrm{H}_{2} \mathrm{O}$ (869.31): C, 49.60; H, 6.59; N, 19.28; found: C, 49.51; H, 6.31; N, 19.85.

$\boldsymbol{N}, \boldsymbol{N}$-Bis(2-aminoethyl)-3-aminopropan-1-ol (7): To a mixture of $N, N$ bis(2-phthalimidoethyl)amine (3.86 g, $10.6 \mathrm{mmol}), \mathrm{K}_{2} \mathrm{CO}_{3}(8.81 \mathrm{~g}, 63.8$ $\mathrm{mmol}), \mathrm{KI}$ ( $88 \mathrm{mg}, 0.53 \mathrm{mmol})$ in MeCN (150 mL), 3-bromo-1-propanol $(5.54 \mathrm{~mL}, 8.86 \mathrm{~g}, 63.8 \mathrm{mmol})$ was added via syringe. The mixture was heated under reflux overnight. The solvent was removed under reduced pressure and $\mathrm{H}_{2} \mathrm{O}(100 \mathrm{~mL})$ was added. The aqueous layer was extracted with $\mathrm{CH}_{2} \mathrm{Cl}_{2}(3 \times 50 \mathrm{~mL})$. The combined organic layers were washed with water, dried with $\mathrm{MgSO}_{4}$, filtered and concentrated under reduced pressure. To the residue, aq. $\mathrm{HCl}(6 \mathrm{M}, 6 \mathrm{~mL})$ was added, and the resulting mixture was heated under reflux overnight and then filtered. The filtrate was stirred in presence of powdered charcoal during $30 \mathrm{~min}$ and filtered again; the volatiles were removed under reduced pressure, and $\mathrm{MeOH}(10 \mathrm{~mL})$ was added. The solution was stirred in presence of ion exchange resin (Amberlite IRA-402, $\mathrm{OH}^{-}$form, $15 \mathrm{~mL}$ ), filtered, and the solvent was removed under reduce pressure, to give the product 7 as a yellow oil (400 mg, $2.48 \mathrm{mmol}, 23 \%) .{ }^{1} \mathrm{H}$ NMR (300 MHz, CD $\left.{ }_{3} \mathrm{OD}\right): \delta$ $1.73(\mathrm{~m}, 2 \mathrm{H}), 2.53-2.62(\mathrm{~m}, 6 \mathrm{H}), 2.73(\mathrm{t}, J=6.3 \mathrm{~Hz}, 4 \mathrm{H}), 3.62(\mathrm{t}, J=6.2$ $\mathrm{Hz}, 2 \mathrm{H}) ;{ }^{13} \mathrm{C}$ NMR (75 MHz, CD $\left.{ }_{3} \mathrm{OD}\right): \delta 30.6\left(\mathrm{CH}_{2}\right), 39.9\left(\mathrm{CH}_{2}\right), 52.3$ $\left(\mathrm{CH}_{2}\right), 56.9\left(\mathrm{CH}_{2}\right), 61.3\left(\mathrm{CH}_{2}\right)$; MS $\left(\mathrm{ESI}^{+}\right): \mathrm{m} / \mathrm{z}(\%) 162.2(100)[\mathrm{M}+\mathrm{H}]^{+}$.

Single-crystal X-ray crystallography: X-ray diffraction data for 2,7BisNP-O4Gua $\times 4 \mathrm{HCl}$ were collected with a Bruker VENTURE / PHOTON 100 CMOS diffractometer with Micro-focus I $\mu$ S source Mo Ka radiation. X-ray diffraction data for 2,7-BisNP-Im (2 $\left.\mathrm{Br}^{-}\right)$were collected with a Bruker X8 APEX II CCD diffractometer with graphitemonochromated Mo-Ka radiation. Crystals were mounted on a CryoLoop (Hampton Research) with Paratone-N (Hampton Research) as cryoprotectant and then flash-frozen in a nitrogen-gas stream at $100 \mathrm{~K}$. For both compounds, the temperature of the crystal was maintained at the selected value by means of a 700 series Cryostream cooling device to within an accuracy of $\pm 1 \mathrm{~K}$. The data were corrected for Lorentz polarization, and absorption effects. The structures were solved by direct methods using SHELXS-97 ${ }^{[62]}$ and refined against $F^{2}$ by full-matrix leastsquares techniques using SHELXL-2017 ${ }^{[63]}$ with anisotropic displacement parameters for all non-hydrogen atoms. Hydrogen atoms were located on a difference Fourier map and introduced into the calculations as a riding model with isotropic thermal parameters. All calculations were performed by using the Crystal Structure crystallographic software package WINGX. ${ }^{[64]}$ The crystal data collection and refinement parameters are given in Supporting Information (Table S1). CCDC-1834477 \& 1834478 contain the supplementary crystallographic data for this paper. These data are provided free of charge by the Cambridge Crystallographic Data Centre.

Nucleic acids: Oligonucleotides (lyophilized, RP-HPLC purity grade) were purchased from Eurogentec, reconstituted in water at a concentration of $100 \mu \mathrm{M}$, and stored at $-20^{\circ} \mathrm{C}$. The equimolar amounts of complementary strands were mixed in the adequate buffer and the solutions were annealed for $5 \mathrm{~min}$ at $80^{\circ} \mathrm{C}$, slowly cooled to ambient temperature to give the duplex. Calf thymus DNA solution $\left(10 \mathrm{mg} \mathrm{mL}^{-1}\right.$, Invitrogen) was diluted in a $10 \mathrm{mM} \mathrm{KAsO}_{2} \mathrm{Me}_{2}, 10 \mathrm{mM} \mathrm{KCl}$ buffer ( $\left.\mathrm{pH} 7.2\right)$ to a nucleotide concentration of $\sim 5 \mathrm{mM}(\sim 50$-fold), and the actual concentration was determined by spectrophotometry, using the extinction coefficient value of $12,824 \mathrm{~cm}^{-1} \mathrm{M}^{-1}$ (base pairs, bp) at $260 \mathrm{~nm}$. Solutions were stored at $+4{ }^{\circ} \mathrm{C}$

Fluorescence-melting experiments: The experiments were performed with 17-mer oligonucleotides 17-NФ (5'-(6-FAM)-CCAGTTCGNAGTAAC CC-3' / 5'- GGGTTACТФCGAACTGG-TAMRA-3', where N = A, T, G or C, $\Phi=\mathrm{THF} / \mathrm{dSpacer}$ ), hybridized in a $10 \mathrm{mM} \mathrm{KAsO} \mathrm{Me}_{2}, 10 \mathrm{mM} \mathrm{KCl}$ buffer ( $\mathrm{pH} 7.2$ ) at a concentration of $25 \mu \mathrm{M}$. The samples (total volume: $25 \mu \mathrm{L}$ ) were prepared by mixing duplex oligonucleotides (final concentration: 0.5 $\mu \mathrm{M}$ ) and ligands (final concentration: $1 \mu \mathrm{M}$ ), in the absence or in the presence of ct DNA competitor (final concentration: 60 or $200 \mu \mathrm{M} \mathrm{bp}$ ) in a $10 \mathrm{mM} \mathrm{KAsO} \mathrm{Me}_{2}, 10 \mathrm{mM} \mathrm{KCl}$ buffer $(\mathrm{pH}$ 7.2). Thermal denaturation profiles were recorded in 96-well plates with a $7900 \mathrm{HT}$ Fast Real-Time PCR apparatus (Applied Biosystems), using fluorescence detection in the FAM channel. After an initial incubation at $25^{\circ} \mathrm{C}$ for $5 \mathrm{~min}$, the temperature was increased to $95^{\circ} \mathrm{C}$ in $0.5^{\circ} \mathrm{C}$ increments every minute. The temperatures of DNA melting transitions were determined from the first-derivative plots of fluorescence intensity versus temperature. Each experimental condition was tested in triplicate.

Fluorimetric APE1 inhibition assay: Recombinant, polyHis-tagged APE1 was purchased from Life Technologies, reconstituted in a buffer containing $10 \mathrm{mM}$ Tris- $\mathrm{HCl}, 50 \mathrm{mM} \mathrm{NaCl}, 1 \mathrm{mM}$ DTT, 0,05 mM Na2EDTA, $200 \mu \mathrm{g} \mathrm{mL}-1$ BSA, and $50 \%$ glycerol $(\mathrm{pH}$ 8.0) at a concentration of $100 \mathrm{nM}$, aliquoted and stored at $-20^{\circ} \mathrm{C}$. The substrate 17-TФ (5'ATTO390-CCAGTTCGTAGTAACCC-3' / 5'-GGGTTACTФCGAACTGG-

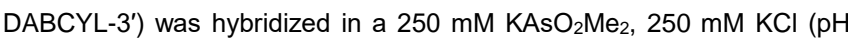
7.2) buffer at a concentration of $20 \mu \mathrm{M}$. For kinetic studies, samples of 17-TФ (final concentration: $0.2 \mu \mathrm{M}$, total volume: $1.00 \mathrm{~mL}$ ) in the absence or in the presence of varied concentrations of ligands were diluted in the APE1 reaction buffer (50 mM HEPES, $50 \mathrm{mM} \mathrm{NaCl}, 1 \mathrm{mM} \mathrm{MgCl}_{2}, 2 \mathrm{mM}$ DTT, $\mathrm{pH}$ 8.0), thermostated at $37{ }^{\circ} \mathrm{C}$ in disposable acrylic semi-micro cuvettes (Evergreen Scientific) for at least $5 \mathrm{~min}$, and an aliquot of APE1 was added. The amount of APE1 was adjusted in order to maintain the same APE1 activity in the absence of inhibitors $\left(v_{0} \approx 0.02 \mathrm{~s}^{-1}\right)$. The realtime fluorescence readings were performed every $12 \mathrm{~s}$ with an Agilent Cary Eclipse spectrofluorimeter running the following experimental parameters: $\lambda_{\mathrm{ex}}=395 \mathrm{~nm} ; \lambda_{\mathrm{em}}=465 \mathrm{~nm}$; slit widths $=10 \mathrm{~nm}$; PMT voltage = $700 \mathrm{~V}, T=37^{\circ} \mathrm{C}$; run duration $=90 \mathrm{~s}$. In order to account for the partial quenching effect induced by some ligands, all fluorescence intensity plots were normalized with respect to the initial intensity $\left(F_{0}\right.$, before addition of the enzyme), and initial reaction velocities $\left(v_{0}\right)$ were determined by manual fitting of linear regions of the curves $F / F_{0}=f(t)\left(r^{2}>0.9\right)$. Each 
experimental condition was tested in triplicate. The enzymatic activity was calculated as a ratio of $v_{0}$ in the presence $\left(v_{0}^{\mathrm{inh}}\right)$ and in the absence of inhibitor ( $\%$ activity $=v_{0}^{\text {inh }} / v_{0}$ ) and plotted as a function of the logarithm of concentration of inhibitor. $\mathrm{IC}_{50}$ values were determined by fitting these plots with a dose-response function.

Real-time fluorimetric assay for AP-DNA cleavage: The doublelabelled uracil-containing precursor 17-TU (5'-ATTO390-CCAGTTCGTAGTAACCC-3' / 5'-GGGTTACTUCGAACTGG-DABCYL-3') was hybridized in a $250 \mathrm{mM} \mathrm{KAsO} \mathrm{Me}_{2}, 250 \mathrm{mM} \mathrm{KCl}$ buffer $(\mathrm{pH} \mathrm{7.2)} \mathrm{at} \mathrm{a}$ concentration of $40 \mu \mathrm{M}$. The batches of the abasic substrate 17-TX were prepared, on a daily basis, by incubation of 17-TU (final concentration: $20 \mu \mathrm{M})$ with UDG (NEB, $\left.5000 \mathrm{U} \mathrm{mL}^{-1}, 1 \mu \mathrm{L}\right)$ in 1X UDG Reaction Buffer (20 mM Tris- $\mathrm{HCl}, 1 \mathrm{mM}$ DTT, $1 \mathrm{mM}$ EDTA, $\mathrm{pH}$ 8, total reaction volume: $120 \mu \mathrm{L})$ for $45 \mathrm{~min}$ at $37^{\circ} \mathrm{C}$. To determine the rates of ligand-induced substrate cleavage, samples of 17-TX (final concentration: $0.2 \mu \mathrm{M}$ in $1.00 \mathrm{~mL}$ of a $10 \mathrm{mM} \mathrm{KAsO} \mathrm{Me}_{2}, 150 \mathrm{mM} \mathrm{KCl}$ buffer, $\mathrm{pH}$ 7.2) were thermostatted at $37{ }^{\circ} \mathrm{C}$ in disposable acrylic semi-micro cuvettes (Evergreen Scientific) and, after $5 \mathrm{~min}$, aliquots of ligands were added to a final concentration of $5 \mu \mathrm{M}$. The real-time fluorescence readings were performed every $12 \mathrm{~s}$ with an Agilent Cary Eclipse spectrofluorimeter running the following experimental parameters: $\lambda_{\mathrm{ex}}=395 \mathrm{~nm} ; \lambda_{\mathrm{em}}=$ $465 \mathrm{~nm}$; slit widths $=5 \mathrm{~nm}$; PMT voltage $=700 \mathrm{~V} ; T=37^{\circ} \mathrm{C}$; run duration $=180 \mathrm{~min}$. The initial slopes $\left(v_{0}\right)$ of the fluorescence intensity vs. time plots were determined by manual fitting of the linear regions of the curves $\left(r^{2}>0.9\right)$. Each experimental condition was tested in triplicate.

To account for the extent of ligand-induced fluorescence quenching, the above-described experiments were performed with a non-cleavable THF analogue 17-TФ (5'-ATTO390-CCAGTTCGTAGTAACCC-3' / 5'-GGGTTACТФСGAACTGG-DABCYL-3'), and quenching factors were calculated as a ratio of time-averaged fluorescence before and after addition of ligands $\left(Q F=F_{\text {with ligand }} / F_{\text {no ligand }}\right)$.

Gel electrophoresis experiments: The uracil-containing strand (5'GGGTTACTUCGAACTGG-3') was 5'-32P-labelled according to standard protocols and purified on a Sephadex column. The radiolabelled precursor 17-TU was prepared by annealing two complementary nonlabelled strands $(40 \mu \mathrm{M})$ in the presence of a small amount of the $5^{\prime}-32 \mathrm{P}$ labelled strand $\left(\sim 2 \times 10^{6} \mathrm{cpm}\right)$, and the abasic substrate 17TX was subsequently obtained by UDG treatment as described above. The radiolabelled substrate (final concentration: $0.2 \mu \mathrm{M}$ ) was incubated at $37^{\circ} \mathrm{C}$ for 1 hour (unless stated otherwise) in the absence or in the presence of ligands (final concentration: $5 \mu \mathrm{M}$ ) in $10 \mathrm{mM} \mathrm{KAsO}_{2} \mathrm{Me}_{2}, 150$ $\mathrm{mM} \mathrm{KCl}$ buffer, $\mathrm{pH} 7.2$ (total volume: $20 \mu \mathrm{L}$ ). Gel loading buffer (formamide / $1 \mathrm{M}$ EDTA / bromophenol blue / xylene cyanol, $12 \mu \mathrm{L}$ ) was added, and samples (aliquots of $8 \mu \mathrm{L}$ ) were loaded onto a denaturing (7 M urea), 20\% polyacrylamide gel and separated at ambient temperature during $2.5 \mathrm{~h}(\sim 1500 \mathrm{~V}, 20 \mathrm{~W})$. After exposure to a phosphorimager screen overnight, the bands were visualized with a Typhoon Trio imager (GE Healthcare) and quantified with ImageQuant TL software (GE Healthcare). Each experimental condition was tested in triplicate. The yields of strand cleavage products were calculated relative to total radioactivity in each lane.

LC/MS analysis of covalent adduct: The uracil-containing precursor 17-TU (5'-CCAGTTCGTAGTAACCC-3' / 5'-GGGTTACTUCGAACTGG$\left.3^{\prime}\right)$ was annealed in a $250 \mathrm{mM} \mathrm{KAsO}_{2} \mathrm{Me}_{2}, 250 \mathrm{mM} \mathrm{KCl}$ buffer $(\mathrm{pH} 7.2)$ at a concentration of $40 \mu \mathrm{M}$. The batches of the abasic substrate 17-TX were prepared by incubation of 17-TU (final concentration: $20 \mu \mathrm{M}$ ) with UDG (NEB, $\left.5000 \mathrm{U} \mathrm{mL}^{-1}, 1 \mu \mathrm{L}\right)$ in $1 \mathrm{X}$ UDG Reaction Buffer $(20 \mathrm{mM}$ Tris$\mathrm{HCl}, 1 \mathrm{mM}$ DTT, $1 \mathrm{mM}$ EDTA, pH 8, total reaction volume: $120 \mu \mathrm{L}$ ) for 45 $\min$ at $37^{\circ} \mathrm{C}$. Samples of $17-\mathrm{TX}$ (final concentration: $0.2 \mu \mathrm{M}$ ) and 2,7BisNP-NH (final concentration: $50 \mu \mathrm{M}$ ) were incubated in $150 \mathrm{mM} \mathrm{KCl}$,
$10 \mathrm{mM} \mathrm{KAsO} \mathrm{Me}_{2}$ buffer, $\mathrm{pH} 7.2$ (total volume: $1000 \mu \mathrm{L}$ ) overnight at $37{ }^{\circ} \mathrm{C}$. Then, the mixtures were concentrated to $\sim 150 \mu \mathrm{L}$, cold $\mathrm{EtOH}$ $(900 \mu \mathrm{L})$ was added and samples were stored overnight at $-20^{\circ} \mathrm{C}$. After centrifugation, the supernatant was removed and the pellet was dried than resuspended in $0.1 \mathrm{M}$ TEAA $(10 \mu \mathrm{L})$. Excess of salt was removed using ZipTip- $\mathrm{C}_{18}$ (Millipore) following the manufacturer's protocol. LC/MS analysis was performed on a Waters $\mathrm{BEH}$ C18 column $(130 \AA, 1.7 \mu \mathrm{m}$, $2.1 \times 50 \mathrm{~mm}$ ), installed on a Waters ACQUITY H-Class UPLC system with a $S Q$ Detector 2 mass detector. Eluent $A: 15 \mathrm{mM}$ tri- $n$-butylamine + $50 \mathrm{mM}$ HFIP, eluent B: $\mathrm{MeOH}$, flow: $0.2 \mathrm{~mL} \mathrm{~min}^{-1}$, gradient: 0 to $1 \mathrm{~min}$ 0-15\% B (linear); 1 to $3.5 \mathrm{~min}, 15-60 \%$ B (linear); 3.5 to $4.5 \mathrm{~min}, 0.1 \%$ formic acid; 4.5 to $6.0 \mathrm{~min}, 100 \% \mathrm{~A}$ (re-equilibration step). Data were analyzed using Waters MassLynx software.

\section{Acknowledgements}

The authors thank Dr. Marie-Paule Teulade-Fichou for helpful and stimulating discussions, Dr. Marcel Hollenstein and Dr. Ivo Sarac (Institut Pasteur, Paris) for help with LC/MS analysis of oligonucleotides, Ms. Séverine Soille, Ms. Flore Migeon and Ms. Isciane Commenge for help with biochemical experiments, and Dr. Michela Zuffo for careful reading of the manuscript. This work was supported by the "IDI 2016" project funded by the IDEX Paris-Saclay (ANR-11-IDEX-0003-02) through a PhD scholarship to C.C.

Keywords: Abasic sites • APE1 • DNA cleavage • macrocycles • DNA repair

[1] J. Lhomme, J. F. Constant, M. Demeunynck, Biopolymers 1999, 52 , 65-83.

[2] P. Fortini, B. Pascucci, E. Parlanti, M. D’Errico, V. Simonelli, E. Dogliotti, Biochimie 2003, 85, 1053-1071.

[3] K. S. Gates, Chem. Res. Toxicol. 2009, 22, 1747-1760.

[4] D. Fu, J. A. Calvo, L. D. Samson, Nat. Rev. Cancer 2012, 12, 104-120.

[5] K. Yang, D. Park, N. Y. Tretyakova, M. M. Greenberg, Proc. Natl. Acad. Sci. 2018, in press (doi: 10.1073/pnas.1813338115).

[6] J. Zhang, M. F.G. Stevens, T. D. Bradshaw, Curr. Mol. Pharmacol. 2012, 5, 102-114

[7] M. S. Bobola, D. D. Kolstoe, A. Blank, M. C. Chamberlain, J. R. Silber Front. Oncol. 2012, 2, 1-9.

[8] H. Erasimus, M. Gobin, S. Niclou, E. Van Dyck, Mutat. Res. - Rev Mutat. Res. 2016, 769, 19-35.

[9] G. Damia, M. D'Incalci, Eur. J. Cancer 2007, 43, 1791-1801.

[10] Y. Zhu, J. Hu, Y. Hu, W. Liu, Cancer Treat. Rev. 2009, 35, 590-596.

[11] R. I. Al-Safi, S. Odde, Y. Shabaik, N. Neamati, Curr. Mol. Pharmacol. 2012, 5, 14-35.

[12] G. Kaur, R. P. Cholia, A. K. Mantha, R. Kumar, J. Med. Chem. 2014, 57 , 10241-10256.

[13] S. S. Laev, N. F. Salakhutdinov, O. I. Lavrik, Bioorg. Med. Chem. 2017, 25, 2531-2544.

[14] A. P. Montaldi, E. T. Sakamoto-Hojo, Clin. Exp. Med. 2013, 13, 279-88.

[15] S. Wei, S. Shalhout, Y. H. Ahn, A. S. Bhagwat, DNA Repair 2015, 27, 9-18.

[16] NCT02395692, Methoxyamine and Temozolomide in treating patients with recurrent glioblastoma. Bethesda (MD), National Library of Medicine (US); https://clinicaltrials.gov/ct2/show/NCT02395692, 2018.

[17] P. Belmont, A. Boudali, J. F. Constant, M. Demeunynck, A. Fkyerat, P. Michon, G. Serratrice, J. Lhomme, New J. Chem. 1997, 21, 47-54. 
[18] B. M. Zeglis, J. A. Boland, J. K. Barton, Biochemistry 2009, 48, 839849

[19] K. Benner, A. Granzhan, H. Ihmels, G. Viola, Eur. J. Org. Chem. 2007, 2007, 4721-4730.

[20] K. Benner, A. Bergen, H. Ihmels, P. M. Pithan, Chem. Eur. J. 2014, 20 9883-9887.

[21] K. Benner, H. Ihmels, S. Kölsch, P. M. Pithan, Org. Biomol. Chem. 2014, 12, 1725-34.

[22] J. Malina, P. Scott, V. Brabec, Nucleic Acids Res. 2015, 43, 5297-5306.

[23] N. Berthet, J. Michon, J. Lhomme, M.-P. Teulade-Fichou, J.-P. Vigneron, J.-M. Lehn, Chem. Eur. J. 1999, 5, 3625-3630.

[24] M. Jourdan, J. Garcia, J. Lhomme, M.-P. Teulade-Fichou, J.-P. Vigneron, J.-M. Lehn, Biochemistry 1999, 38, 14205-14213.

[25] N. Kotera, F. Poyer, A. Granzhan, M.-P. Teulade-Fichou, Chem. Commun. 2015, 51, 15948-15951.

[26] N. Kotera, A. Granzhan, M.-P. Teulade-Fichou, Biochimie 2016, 128 129, 133-137.

[27] J. Pierre, J. Laval, J. Biol. Chem. 1981, 256, 10217-10220.

[28] T. Behmoaras, J. J. Toulmé, C. Hélène, Nature 1981, 292, 858-859.

[29] A. J. Kurtz, M. L. Dodson, R. S. Lloyd, Biochemistry 2002, 41, 7054 7064.

[30] A. Fkyerat, M. Demeunynck, J. F. Constant, P. Michon, J. Lhomme, J. Am. Chem. Soc. 1993, 115, 9952-9959.

[31] V. Steullet, S. Edwards-Bennett, D. W. Dixon, Bioorganic Med. Chem. 1999, 7, 2531-2540.

[32] M. Perigolo De Oliveira, J. F. Constant, M. Peuchmaur, I. Pitta, J. L. Décout, Chem. Res. Toxicol. 2013, 26, 1710-1719.

[33] I. G. Minko, A. C. Jacobs, A. R. De Leon, F. Gruppi, N. Donley, T. M. Harris, C. J. Rizzo, A. K. McCullough, R. S. Lloyd, Sci. Rep. 2016, 6, 28894.

[34] Y. S. Abe, S. Sasaki, Bioorganic Med. Chem. 2016, 24, 910-914.

[35] J. M. Barret, C. Etievant, J. Fahy, J. Lhomme, B. T. Hill, Anticancer Drugs 1999, 10, 55-65

[36] S. N. Andres, M. J. Schellenberg, B. D. Wallace, P. Tumbale, R. S. Williams, Environ. Mol. Mutagen. 2015, 56, 1-21.

[37] M. V. Baker, M. J. Bosnich, C. C. Williams, B. W. Skelton, A. H. White, Aust. J. Chem. 1999, 52, 823.

[38] E. Alcalde, N. Mesquida, L. Pérez-García, C. Alvarez-Rúa, S. GarcíaGranda, E. García-Rodriguez, Chem. Commun. 1999, 295-296.

[39] A. Caballero, N. G. White, P. D. Beer, Angew. Chem. Int. Ed. 2011, 50 1845-1848.

[40] F. Zapata, A. Caballero, N. G. White, T. D. W. Claridge, P. J. Costa, V. Félix, P. D. Beer, J. Am. Chem. Soc. 2012, 134, 11533-11541.

[41] A. Granzhan, E. Largy, N. Saettel, M.-P. P. Teulade-Fichou, Chem. Eur. J. 2010, 16, 878-889.
[42] M. Jourdan, A. Granzhan, R. Guillot, P. Dumy, M.-P. Teulade-Fichou, Nucleic Acids Res. 2012, 40, 5115-5128.

[43] N. Kotera, R. Guillot, M.-P. Teulade-Fichou, A. Granzhan, ChemBioChem 2017, 18, 618-622.

[44] C. Yung-Chi, W. H. Prusoff, Biochem. Pharmacol. 1973, 22, 3099-3108.

[45] G. Rai, V. N. Vyjayanti, D. Dorjsuren, A. Simeonov, A. Jadhav, D. M. Wilson, D. J. Maloney, J. Med. Chem. 2012, 55, 3101-12.

[46] M. C. Rideout, B. Liet, D. Gasparutto, N. Berthet, Anal. Biochem. 2016 513, 93-97.

[47] R. Male, V. M. Fosse, K. Kleppe, Nucleic Acids Res. 1982, 10, 63056318.

[48] A. Mazumder, J. A. Gerlt, M. J. Absalon, J. A. Stubbe, R. P. Cunningham, J. Withka, P. H. Bolton, Biochemistry 1991, 30, 11191126.

[49] R. Rahimoff, O. Kosmatchev, A. Kirchner, T. Pfaffeneder, F. Spada, V. Brantl, M. Müller, T. Carell, J. Am. Chem. Soc. 2017, 139, 1035910364.

[50] K. M. Johnson, N. E. Price, J. Wang, M. I. Fekry, S. Dutta, D. R. Seiner, Y. Wang, K. S. Gates, J. Am. Chem. Soc. 2013, 135, 1015-1025.

[51] N. E. Price, K. M. Johnson, J. Wang, M. I. Fekry, Y. Wang, K. S. Gates, J. Am. Chem. Soc. 2014, 136, 3483-3490.

[52] Y. Zhiyu, N. E. Price, K. M. Johnson, W. Yinsheng, K. S. Gates, Nucleic Acids Res. 2017, 45, 6275-6283.

[53] T. Marsoner, O. P. Schmidt, T. Triemer, N. W. Luedtke, ChemBioChem 2017, 18, 894-898.

[54] A. C. Komor, C. J. Schneider, A. G. Weidmann, J. K. Barton, J. Am. Chem. Soc. 2012, 134, 19223-33.

[55] K. M. Boyle, J. K. Barton, J. Am. Chem. Soc. 2018, 140, 5612-5624.

[56] D. Melton, C. D. Lewis, N. E. Price, K. S. Gates, Chem. Res. Toxicol. 2014, 27, 2113-2118.

[57] J. T. Sczepanski, R. S. Wong, J. N. McKnight, G. D. Bowman, M. M. Greenberg, Proc. Natl. Acad. Sci. 2010, 107, 22475-22480.

[58] J. T. Sczepanski, C. Zhou, M. M. Greenberg, Biochemistry 2013, 52 , 2157-2164.

[59] M. M. Greenberg, Acc. Chem. Res. 2014, 47, 646-655.

[60] J. Novotna, A. Laguerre, A. Granzhan, M. Pirrotta, M.-P. TeuladeFichou, D. Monchaud, Org. Biomol. Chem. 2015, 13, 215-222.

[61] A. Granzhan, M.-P. Teulade-Fichou, Tetrahedron 2009, 65, 1349-1360.

[62] G. M. Sheldrick, SHELXS-97, Program for X-Ray Crystal Structure Solution, University Of Gottingen, Germany, 1997.

[63] G. M. Sheldrick, Acta Crystallogr. Sect. C Struct. Chem. 2015, 71, 3-8.

[64] L. J. Farrugia, J. Appl. Crystallogr. 1999, 32, 837-838. 


\section{Entry for the Table of Contents}

\section{FULL PAPER}

Cationic naphthalenophanes bind to abasic (AP) sites in doublestranded DNA with high affinity and selectivity. Depending on their molecular structure, this process may lead to efficient indirect inhibition of enzymatic (APE1) hydrolysis of AP-sites, ligandinduced DNA cleavage, or formation of covalent ligand-DNA adducts.
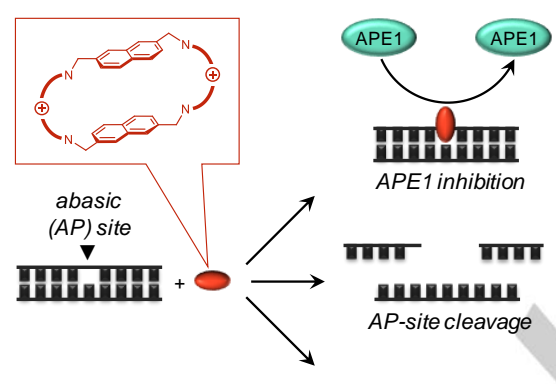

APE1 inhibition

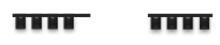

PIPTHFT

AP-site cleavage जाएकी जाएा

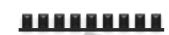

covalent adduct
Coralie Caron, Xuan N. T. Duong,

Régis Guillot, Sophie Bombard, Anton

Granzhan*

Page No. - Page No.

Interaction of Functionalized

Naphthalenophanes with Abasic

Sites in DNA: DNA Cleavage, DNA

Cleavage Inhibition, and Formation

of Ligand-DNA Adducts 